\title{
Wangil Midden: a Late Prehistoric Site, With Remarks on Ethnographic Pottery Making
}

\author{
Peter Veth¹, Matthew Spriggs², Sue 0'Connor², and Aliza Diniasti Saleh³ \\ 1. Research Unit, Australian Institute of Aboriginal and Torres Strait Islander Studies, \\ Acton, Canberra, ACT, Australia \\ 2. Department of Archaeology and Natural History, Research School of Pacific and Asian Studies, \\ The Australian National University, Canberra, ACT, Australia \\ 3. Puslit Arkenas, Jakarta, Indonesia
}

\section{Introduction}

During our surveys around the Aru Islands from 1995-97 we noted a number of mounded and linear middens, some of considerable extent (see Chapter 4, this volume). Only one of these coastal sites, an extensive mounded midden on the northwestern littoral of Wamar Island (Figs 6.1-6.3), was excavated. It is located approximately one kilometre from the modern village of Wangil. This paper documents the test pitting and analysis of the Wangil midden.

Many of the coastal middens recorded in the Aru group (Chapter 4, this volume) were noted to contain both plain and decorated pottery, and this raised the possibility of characterizing and dating assemblages from the Neolithic through to the historic period. This had been identified as one of the major research aims of the Aru Project (see Chapter 1, this volume; Spriggs 1998).

It was clear from the presence of imported ceramics that many of these sometimes extensive coastal middens were quite recent. This was demonstrated in several cases by the presence of glass bottles eroding from the deposits that could be dated to the 18th and 19th centuries, possibly attesting to a colonial-era trade in prized marine commodities such as pearl shell. Previous survey had located midden complexes along the northwestern coastline and at various localities along the central east and southeastern sectors of the island group (see Chapter 4, this volume). Surface scatters of shellfish were less commonly sighted than buried linear and mounded forms, presumably due to the better preservation of the latter due to their greater inherent mass and resistance to the leaching of calcium carbonate in the tropics.

The island of Wamar had yielded evidence from survey of the presence of potentially older coastal midden deposits than seen elsewhere in the island group, some of which appeared on initial inspection to lack pottery and perhaps represent mid-Holocene 'Mesolithic' sites. Others, particularly in the Wangil area, seemed to have the possibility to provide a long pottery sequence for an area predicted to have a 4000-3500 year old local ceramic tradition on the basis of 
comparison with areas to the north and southwest (Bellwood 1997:Chapter 7). Examination of the Dobo to Durjela vehicle track during our 1995 survey revealed that construction of the track had disturbed several shell middens in this area (Site 10, see Chapter 4, this volume). Small-scale sand quarry areas had exposed red-slipped and other decorated sherds that superficially at least resembled those found in Neolithic and Metal Age contexts elsewhere in Island Southeast Asia (Bellwood 1997:224-34, 297). These sherds are illustrated and described later in this chapter.

In 1997, the potential of the Wangil

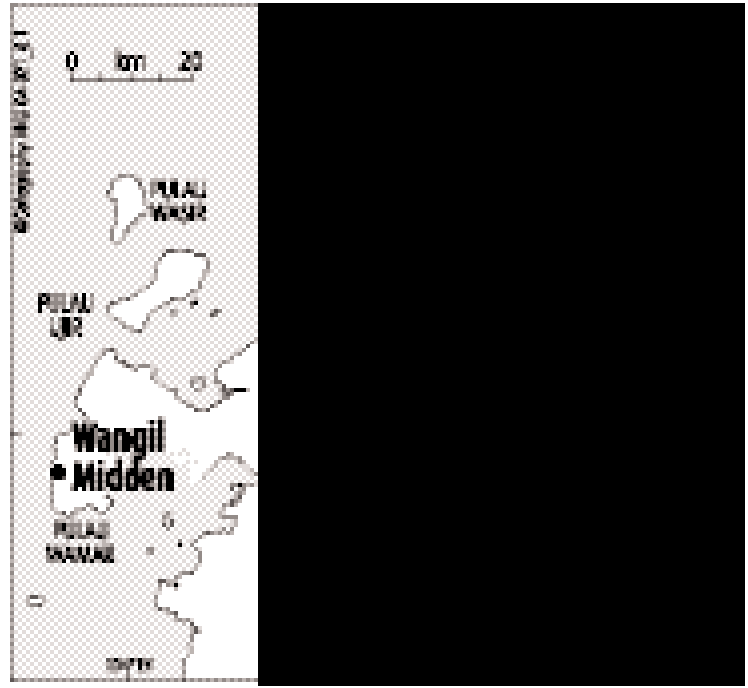

Figure 6.1 Wangil Midden: the site's location on the west coast, and the modern pottery making village of Batu Lei on the island of the same name on the east coast midden sites was explored through excavation by Veth and Diniasti. The cave site of Liang Lemdubu had been excavated in the previous year. At that site only a very small number of non-diagnostic pottery sherds had been recovered from the uppermost two spits, dating to the last two thousand years (see Chapter 9, this volume). The general dearth of pottery in the upper spits of this intensively occupied site (apart from whole specimens of Chinese tradeware at an adat shrine on the surface) suggested that - not unpredictably - very different patterns of pottery usage and discard had occurred between the coastal midden sites and the interior caves. The excavation of Wangil, therefore, provided data for the first step of a comparison of pottery assemblages for an area whose late Holocene archaeology was terra incognita. At the

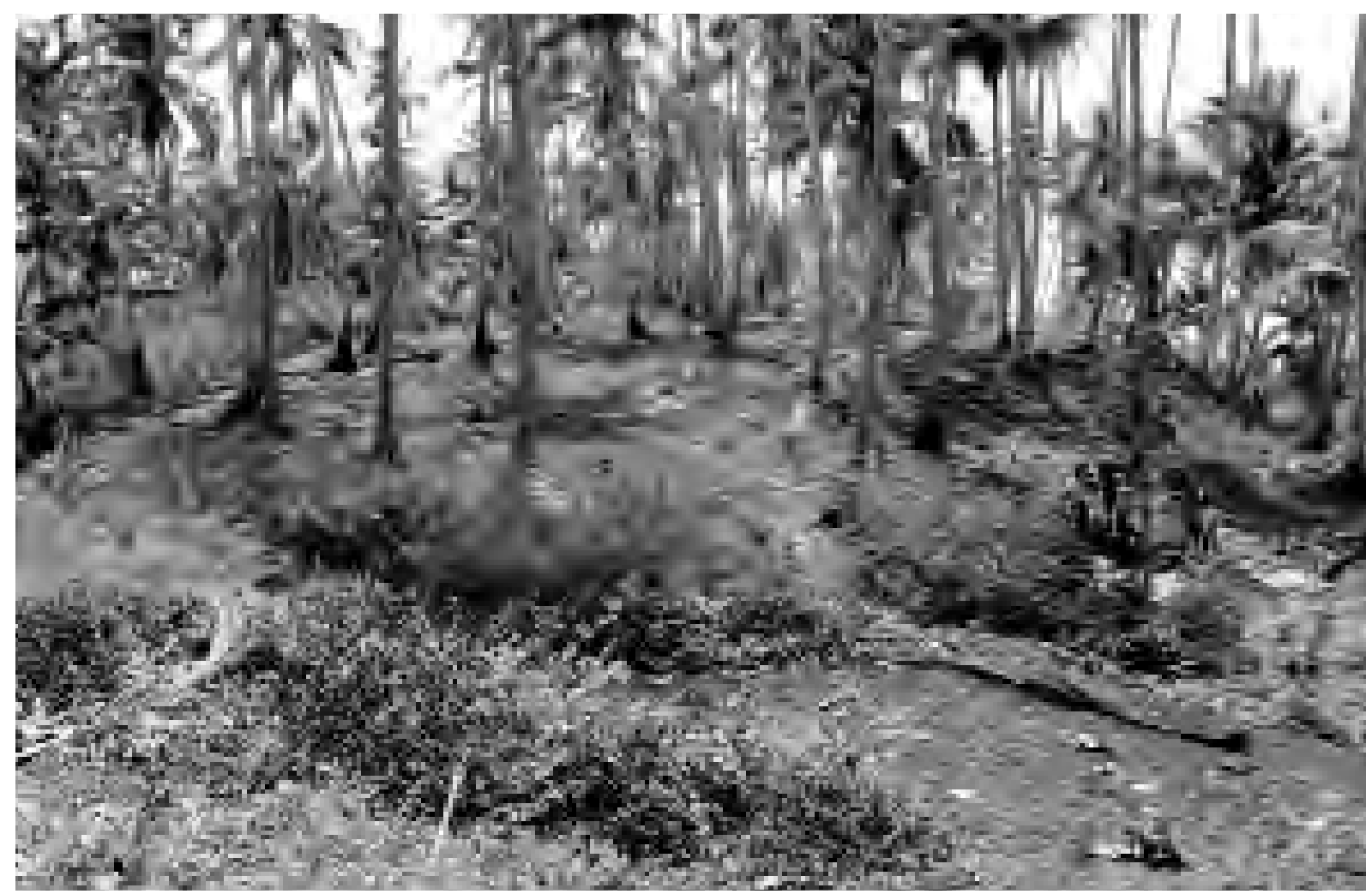

Figure 6.2 Wangil Midden: southern view of the midden 


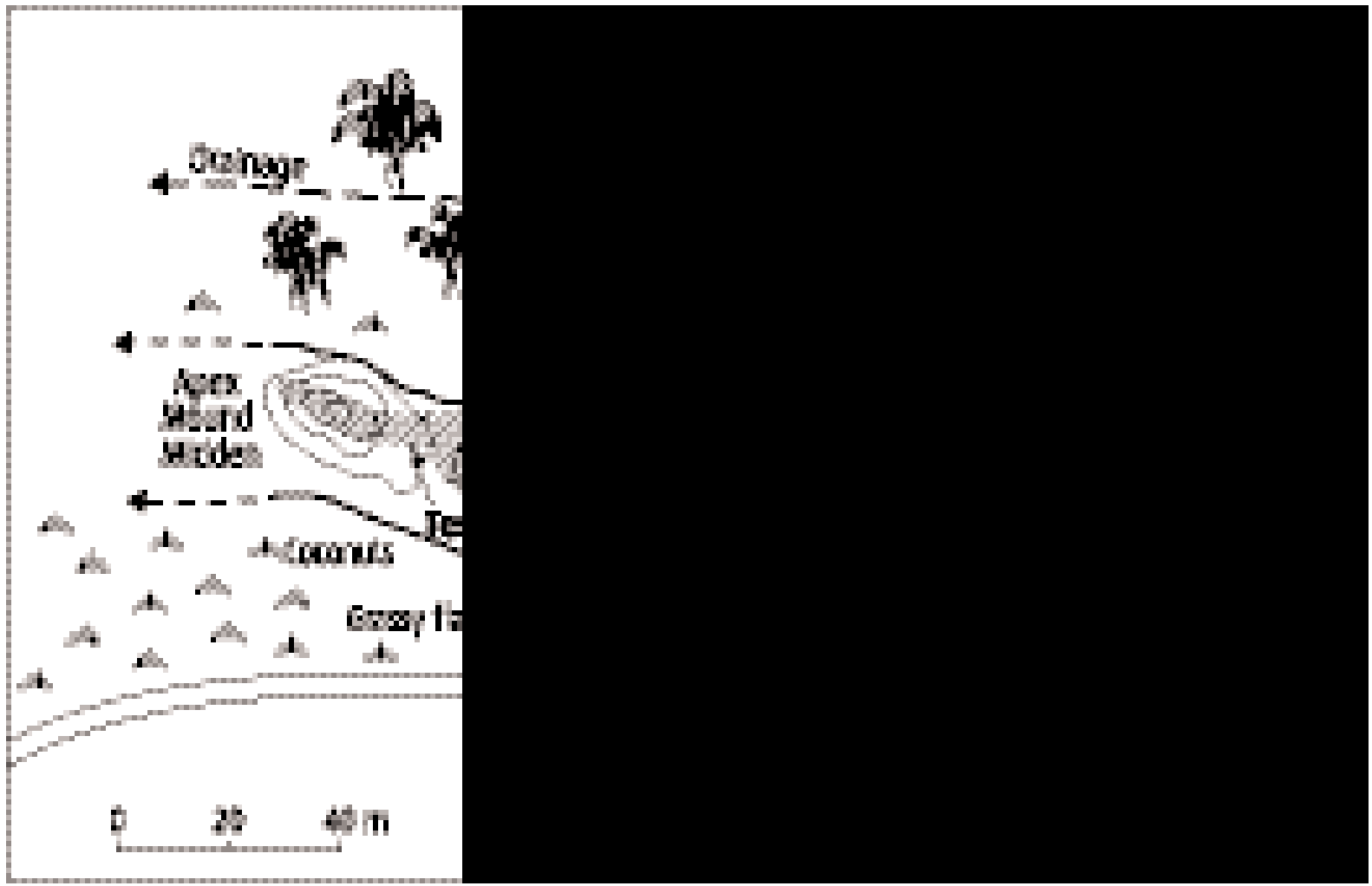

Figure 6.3 Wangil Midden: plan of the midden

same time that Wangil was being investigated, a further pottery assemblage was being recovered in the upper levels of Nabulei Lisa cave in the interior of Aru. It will be dealt with in the report on that site (Chapter 7, this volume).

\section{Historical Records on Wangil and on Pottery Production in Aru}

Of all the naturalists and explorers who visited the Aru Islands by the late 19th century, it is only the records of German naturalist Hugo Merton (1910) that provide specific details on the village of Wangil and of local pottery making traditions. Merton traveled through the Aru group between October 1907 and August 1908.

He describes the village of Wangil as one of two large villages on the west side of Wamar Island (also Warmar), the other being Durjela:

Almost all the huts of Wangil stood at ground level and in rows. It especially occurred to us that every hut was surrounded by a small garden and every property was surrounded by a fence. In the middle of the village is the main street, from which side streets branch off to both right and left sides (Merton 1910:21, 87, translation by A. and A. Veth, and following).

A Patti (hereditary leader) had his residence at Wangil. These conditions were still in place when the team worked on the midden site in 1997.

Merton $(1910: 42,163)$ records three centres of pottery production in the Aru Islands during his lengthy journey: at Watulai (Batu Lei) on the east coast (Figs 6.1, 6.4); at Maikoor on the southwest coast; and at the site of Samang, on the island of Wokam to the north of Wamar. At the latter, a pit had been dug as a source of clay for pottery production. Merton purchased various kinds of pots from the inhabitants of Samang, mentioning water jars, sago ovens, meat pots and clay hearth supports. All but the meat pots - which came from Batu Lei - were manufactured in 
Samang. There are in fact several more pottery making villages than have been previously recorded (Jock Hughes, pers. comm. 1996; cf. Ellen and Glover 1974:353). some detail:

Merton (1910:115) describes the production of pottery at Maikoor (Maekoor village) in

Only the women and girls occupy themselves with it. The potter's wheel is here, as on all neighbouring groups of islands, unknown. The vessels are made in the following primitive method. A lump of loam-coloured clay is first kneaded by hand, or with a pounder, then superficially rounded, and after that hollowed out by hand; once this has been roughly achieved to a certain point, then the mass is beaten for some time by a rounded stone [anvil] and by a paddle for beating simultaneously from the outside and inside, until the whole wall of the vessel, which is continually turned about in the process, has gradually become evenly thin and firm. It is surprising how the vessels turn out to be quite regular, with this of itself so primitive procedure. When they are sufficiently dried and smoothed on the outside with fine sand, they are then placed on a brushwood fire in order to be finished. It is not surprising that with such a primitive method these products turn out to be very uneven and many a vessel is destroyed in the process. Various kinds of pottery are produced here: water containers with narrow necks, vessels with wider mouths as cooking vessels, and sago ovens of various sizes. These consist of a square box which contains a number of rectangular compartments. Each compartment has the shape of a sago loaf. Two handles on both sides of the sago ovens serve to take it off the fire at the right moment. The distinctive sirih [lime] containers are also made of pottery. They are the only vessels which are decorated, at the most with simple linear ornaments; on the water jars and cooking pots small impressions are made by the finger-nail on the lip of the vessel rim or on the neck.

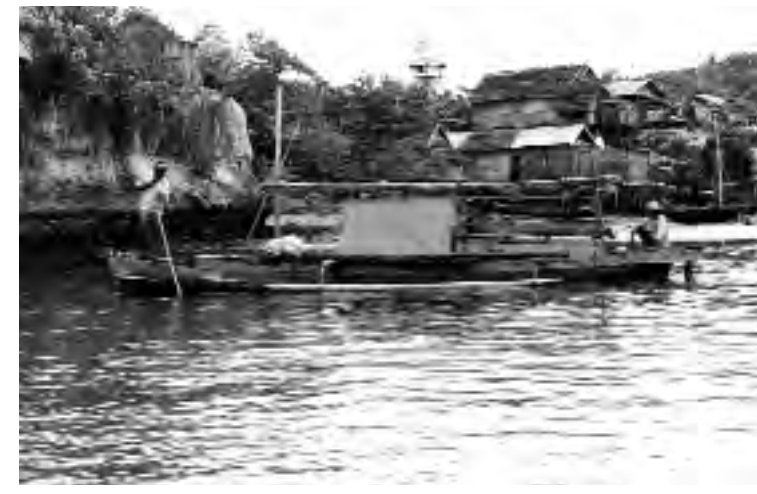

Figure 6.4 The village of Batu Lei on the east coast

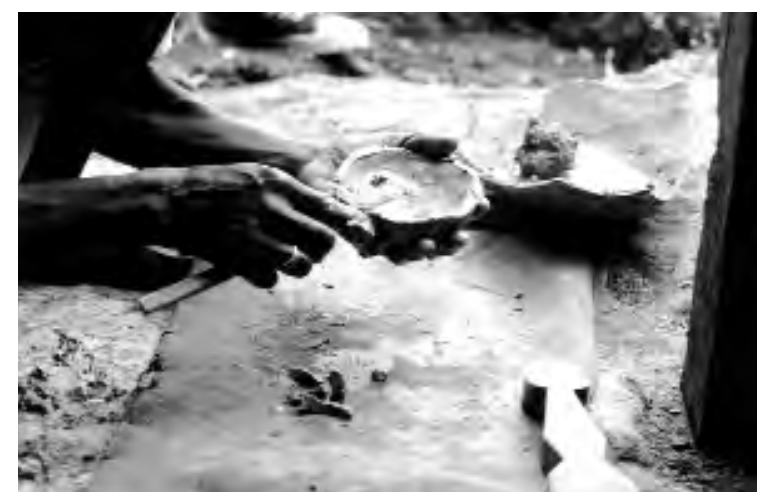

Figure 6.5 Pottery production at Batu Lei showing sand temper, clay and paddle
Finally, Merton documents the similarity of some pottery vessels in the Aru group to containers made in Java of brass and concludes ' ... one has to assume that these served the Aruese only as a model ...' (Merton 1910:42). The majority of pots he describes as made in Aru appear to belong to the common Eastern Indonesian ethnographic types (Ellen and Glover 1974; Gasser 1969).

The Maikoor manufacturing technique as described by Merton consists of impact from a solid lump, finished with paddle and anvil. In Batu Lei on 13 November 1996 we witnessed a pottery making demonstration - by no means the ideal method of observing such techniques. The information as collected at Batu Lei and given here represents an extremely superficial study and is only presented in the absence of any more detailed studies known to us. The method used was similar to that described for Maikoor. The clay is apparently obtained from another island, and the sand temper is assumed to be from beach deposits (Figs 6.5, 6.6). The pot forms being made in Batu Lei included an open bowl probably for mixing sago paste or pepeda, 
a restricted orifice water container with a hollowed base, an ashtray or asbak which looked more like a lamp with a handle, mortars and pestles (cobe dan muntu), and sago ovens or forna (Fig. 6.7). The pots are decorated with a red pigment painted decoration (Figs 6.6, 6.7). Water jars, bowls, and mortar and pestle sets sell for 2000 rupiah, and the asbak form for 1500 rupiah. There seem to be about four to seven potters in the village, but only two were said to be regularly involved in pot making. We were told that until recently the industry was on a larger scale but was by 1996 in serious decline. This might explain why no-one had come that year to Papakulah Besar and Kepala Sungai to sell pots, as people remarked in those two places.

As at Maikoor, the technique as observed by us in the manufacture of a mortar was impact from a solid lump, with paddle and anvil finishing (Fig. 6.5). The potter had two wooden paddles of different thickness and the anvils were themselves of baked clay rather than stone. The clay and sand were mixed using salt water, with sand continuing to be added to the mix when some cracking of the base of the pot appeared during manufacture. The mineral paint

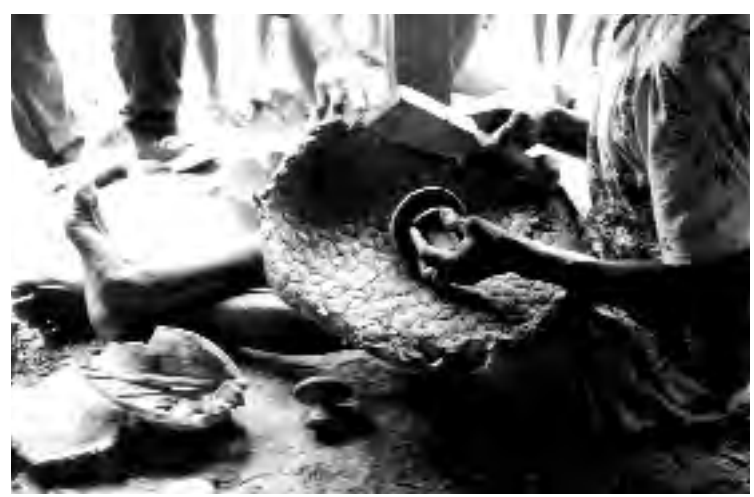

Figure 6.6 Pottery production at Batu Lei showing baler shell with pigment for painting pottery

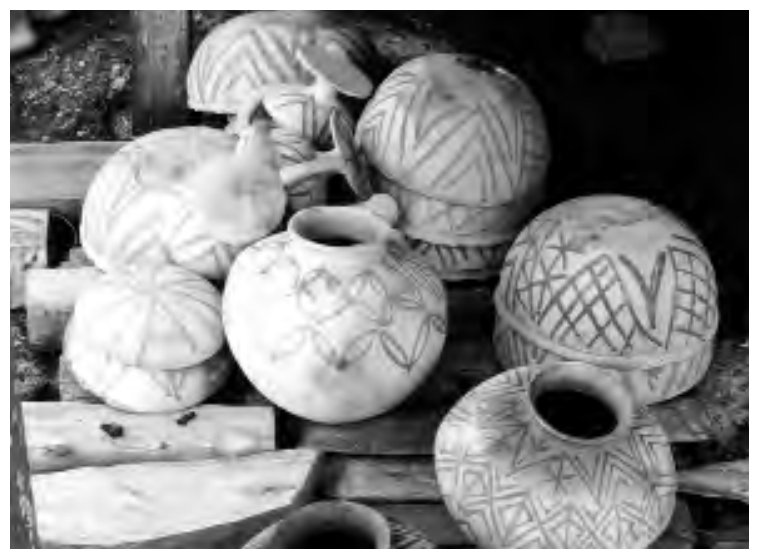

Figure 6.7 Contemporary Batu Lei pottery vessel forms is mixed with salt water and painted on with a stick. The pots are said to be dried in the sun for two or three hours before they are painted and then fired. Some of the pots of the woman we observed were further decorated with lip notching.

The firing area was adjacent to the village playing field in an area exposed to the wind. Coconut leaves were noted to have been used as fuel in the firing. Water jars are said to be tested for leaks post-firing and then caulked traditionally by rubbing with mangrove fruit. We were told that soap is now used!

Pétrequin and Pétrequin (1999) present a general overview of pottery production techniques in the Eastern Indonesian and New Guinea regions. Their Figure 1 gives a graphic representation of pottery production at Kumul, a village on an island just north of Batu Lei and in the same language group. Techniques are clearly similar to Batu Lei. They also illustrate pottery produced at Barakai, an island south of Batu Lei and in a different language group (1999:Fig. 6).

\section{Physical Setting of the Site and Method of Excavation}

The area chosen for excavation at Wangil is located 135m inland on a north-south oriented ridge parallel to the coast and rising southwards (Figs 6.2,6.3). The geology of the area consists of an uplifted arenaceous limestone mantle overlying older muddy sands of shallow marine origin. However, the ridge lacks any limestone debris and consists of sandy clays, so it may represent the eroded remnant of a former valley fill or fan. A sand ridge plain of medium coralline sand extends westwards $100 \mathrm{~m}$ to the top of a gentle beach. This area supports a coastal forest of Barringtonia asiatica, Hibiscus tiliaceus, and Calophylum inophyllum, with scattered coconuts above a scrub of 


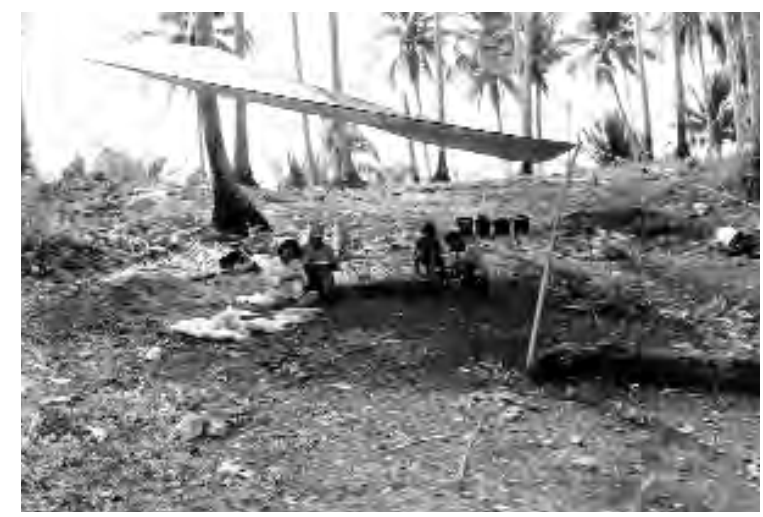

Figure 6.8 Wangil Midden: view of test pit during excavation

Argusia argenteum and Scaevola sericea. The ridge has steep, possibly wave-cut sides and an open low woodland of Macaranga sp. and other secondary shrubs. It falls inland to a swampy plain at $+0.85 \mathrm{~m}$ above high water with scattered Pandanus and secondary scrub, and groves of sago palm (Metroxylon sagu) (see Fig. 6.3).

The mound is approximately eight metres above the current high water mark. A bitumen road follows the coastal base of the ridge and has cut into the earliest of the sand ridges. It is from here that the sand quarry assemblage was collected.

Wangil Midden - Northern section

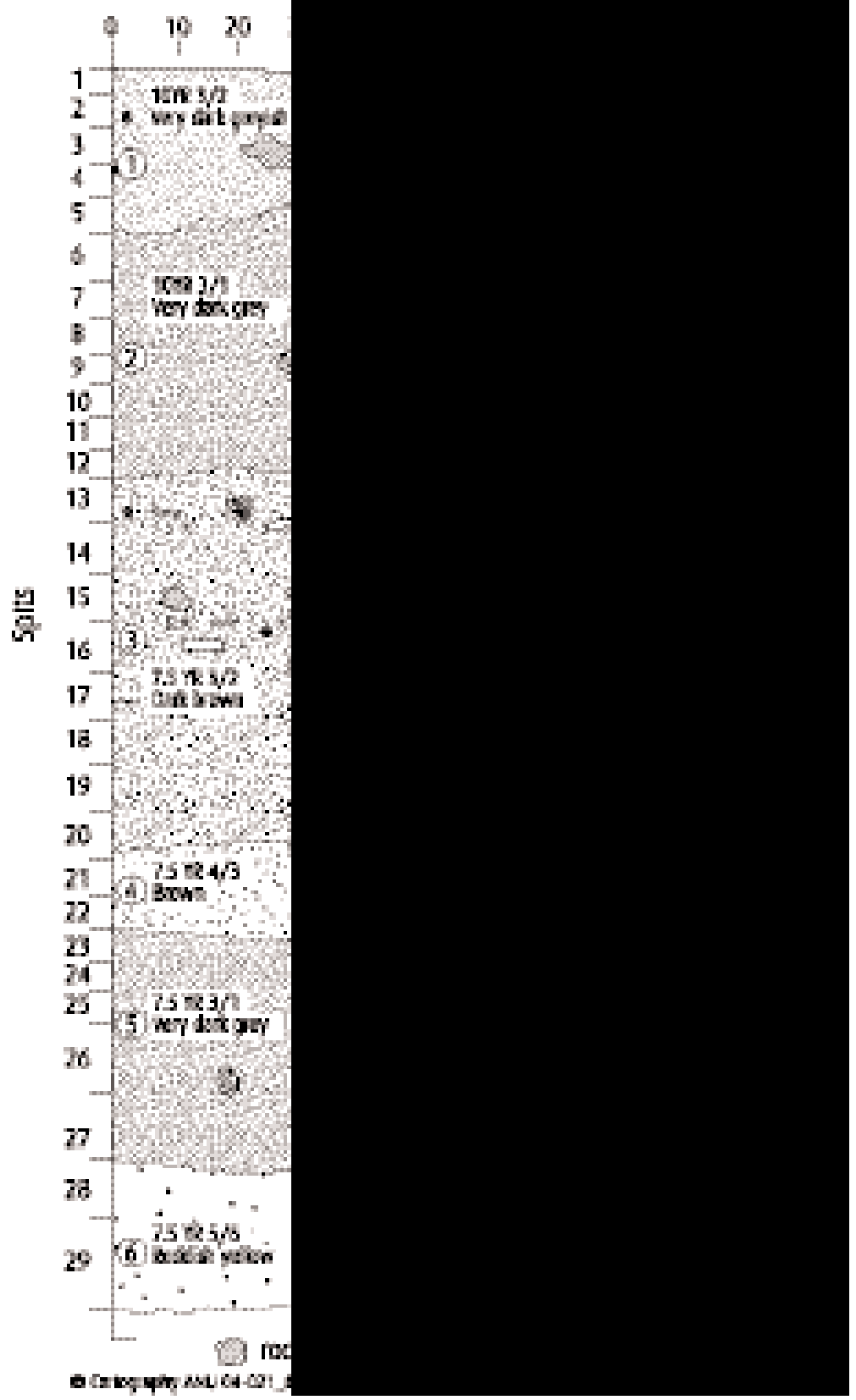

Figure 6.9 Wangil Midden: north section of the test pit
Shell midden is exposed on the central and upper slopes of the ridge, containing a variety of marine shellfish, plain and undecorated pottery, and broken quartzite pebbles and cobbles. A coconut grove and garden plots are sited on the mound and these expose midden where disturbance has been most recent. The major exposure of midden measures over $110 \mathrm{~m}$ in length north-south, and some $30 \mathrm{~m}$ in width east-west (Fig. 6.3).

The low beach ridges to the west of the uplifted limestone ridge and mound area, where the cultural deposit is located, are thought to have formed as a result of progradation beginning in the mid-Holocene. At the time of sea level stabilization the uplifted ridge may have been an isthmus flanked by open sea on one side and a tidal lagoon with mangrove stands on the other. Subsequent infilling of the mouth of the palaeolagoon would have shifted the basin towards a freshwater regime with the subsequent establishment of sago (see below).

Cuttings through the edge of the ridge and mound from the construction of the road, and erosional rills and gullies on the 
slopes, indicated that the cultural deposit was likely to have significant depth. A $1 \mathrm{~m}^{2}$ test pit was located on the northern slope of a minor saddle on the ridge (Figs 6.3, 6.8). The GPS location is $5^{\circ} 46.024^{\prime} \mathrm{S}, 134^{\circ} 11.63^{\prime} \mathrm{E}$. It was located so as to sample deposits which did not appear to have been seriously disturbed through gardening activity, and where the density of surface pottery was highest for the upper portions of the mound. This test pit reached sterile deposits at almost two metres below surface level, confirming the appreciable depth of deposit at this point (Figs 6.9, 6.10). While the site is referred to as a midden, the

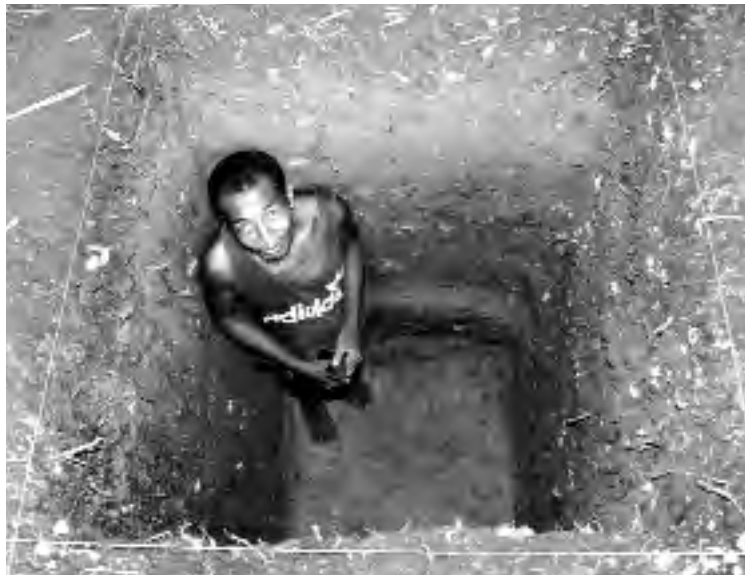

Figure 6.10 Wangil Midden: the $1 \mathrm{~m}^{2}$ test pit shell, other faunal material and pottery are fairly sparsely distributed in a sediment matrix.

The surface deposit of the test pit was characterized by very dark grayish brown clays (10YR $3 / 2$, Munsell ${ }^{\circledR}$ Soil Colour Charts) with loose particles of charcoal, rootlets of grass and coconut husk (Fig. 6.9). Plain pottery fragments and sherds of Chinese glazed ware were present in addition to several vertebrae from a large pelagic fish and valves of the mud whelk Anadara granosa.

Deposits were removed in five centimetre spits unless features or stratigraphic changes were noted; the average depth of spits increased in the lower layers largely due to the large size of included pottery fragments and due to the extreme compaction of the clays. All recoveries were processed through a nest of $2.5 \mathrm{~mm}$ and five millimetre sieves. Volumetric records were noted for each removal and spit so that corrected volumes could be calculated to compare cultural residues in a meaningful fashion. Records of Munsell colours were recorded in situ. A column sample was made on the southern face of the test pit at the end of the excavation, to retrieve solid sub-samples. Oriented sub-samples were also taken on this face at two centimetre intervals so that palynological analysis could be carried out. A $250 \mathrm{~cm}$ core was also taken by Hope within the adjacent sago swamp, 30m northwest of the midden excavation (see Chapter 2 this volume; Fig. 6.3).

\section{Summary Description of Test Pit and Stratigraphy}

The test pit recovered midden to nearly two metrese depth below surface level, containing mainly marine shellfish and plain and decorated pottery. The stratigraphy for the northern section is shown in Figure 6.9. Other fauna were rare, with only turtle carapace and portions of dugong rib recovered from Spits 3 and 13, and pig elements from several spits between Spits 1 and 19. A pig mandible with teeth intact was recovered from Spit 17 (these are accessioned with Puslit Arkenas Arkeologi Nasional in Jakarta, as is the decorated pottery).

Layer 1 (Spits 1-5) comprises very dark grayish brown clays (10YR 3/2) and contained copious quantities of shellfish and pottery fragments, including sections of rims, handles and bases (Fig. 6.9). The turtle and dugong elements come from this layer. The density of pottery decreases at the base of this layer.

Layer 2 (Spits 6-12) comprises a very dark gray clay (10YR 3/1) with a lower density of cultural residues.

Layer 3 (Spits 13-20) is dark brown (7.5YR 3/2) and has a high density of both shellfish and pottery (Fig. 6.9). The pig elements were recovered from this layer. Decorated pottery was recovered from Spits 16-20, and is described below. The density of cultural material decreased markedly towards the base of this layer. 
Layer 4 (Spits 21-22) is an extremely clayey brown (7.5YR 4/3) strata with very little pottery or shellfish in its lower portion.

Layer 5 is a very dark gray clay $(7.5 Y \mathrm{R} 3 / 1)$ containing negligible economic shellfish but still appreciable quantities of pottery, including some decorated specimens.

Layer 6 (Spits 28-29) comprised reddish yellow clays (7.5YR 5/6), which become culturally sterile by the base of the excavation at two metres depth. Marine fauna and undecorated pottery are only present in very small quantities in the upper part of the layer.

\section{Dating the Cultural Assemblages}

Dates were obtained from three in situ samples of charcoal and one of marine shell, and aimed to sample the boundary between Layers 2 and 3, the base of Layer 3, and the lowest assemblage of pottery and shellfish reliably assigned to Layer 4. Samples Wk-6097 and OZE232 reliably bracket the majority of the decorated pottery recovered from the site in Layer 3, while sample OZE233 provides a conservative date for first deposition of pottery and economic shellfish at this locality. The dates from Layers 3 and 4 (OZE232 and OZE233) are vertically separated by only approximately $10 \mathrm{~cm}$ of deposit, and statistically overlap to represent essentially the same date. The dates were calibrated using CALIB REV4.4.2 (Stuiver and Reimer 1998) and are presented at the maximum probability distribution at 2 sigma.

Table 6.1 Wangil Midden: uncalibrated and calibrated (CALIB REV4.4.2) results for dated samples of charcoal and shell recovered from the test excavation (na = information not available)

\begin{tabular}{|c|c|c|c|c|c|c|}
\hline LAB CODE & LAYER & SPIT & MATERIAL & $\delta^{13} \mathrm{C}$ & CONVENTIONAL ${ }^{14} \mathrm{C}$ & CALIBRATED ${ }^{14} \mathrm{C}$ \\
\hline Wk-6097 & 2 & 13 & Charcoal & -28.2 & $450 \pm 90 \mathrm{BP}$ & $644-307$ \\
\hline OZE232 & 3 & 20 & Charcoal & -25.0 & $735 \pm 60 \mathrm{BP}$ & $786-556$ \\
\hline OZE233 & 4 & 24 & Charcoal & -25.0 & $725 \pm 60 \mathrm{BP}$ & $760-554$ \\
\hline ANU-11111 & Base of 4 & 28 & Marine shell & na & $1080 \pm 70 \mathrm{BP}$ & 1167-771 \\
\hline
\end{tabular}

The location of the dates against spits on Figure 6.9 indicates that the rate of deposition was rapid at this locality following first occupation - possibly due to clearing, firing and slope instability - and most of the deposit between Layers 4 and 2 accumulated over a few hundred years. The majority of decorated pottery recovered from the site, and indeed the greatest volume of all pottery recovered also falls within this period.

\section{Environmental Data}

Pollen was not preserved in the silty sands of the Wangil midden. However, the swampy area inland of the midden was augered and produced a pollen sequence. The augered area is a plain about $0.9 \mathrm{~m}$ above modern high water. The augered section (described in detail in Chapter 2, this volume) revealed peat overlying swampy loams with mottled brown clays in the upper $85 \mathrm{~cm}$, giving way to black sandy silts with wood and gastropods down to $240 \mathrm{~cm}$. Mangrove pollen increases from $240-160 \mathrm{~cm}$, remains at a maximum to $70 \mathrm{~cm}$ and then declines rapidly, suggesting a succession from an open inlet at the base through tidally flooded mangrove that silted up and became dry land. This is supported by the presence of estuarine shell below $85 \mathrm{~cm}$. Dates on organic matter show that this estuarine phase accumulated rapidly, reaching modern sea level about 6000 years ago at $60 \mathrm{~cm}$, after which sediment build-up under seasonal swamp conditions has been very slow. 


\section{Summary of Artefacts and Economic Fauna}

Artefacts comprised mainly undecorated pottery, with a minor component of decorated sherds (see below). Small sherds of Chinese ceramics were recovered from Spits 1, 2, and 15. Economic fauna comprised mainly marine shellfish and these are discussed below. Portions of dugong rib bones were recovered from Spits 3 and 13. Terrestrial faunal remains were extremely sparse comprising pig elements in Spits 1, 4, 5, 12, 13, 15, 17, and 19.

All pottery recovered from the excavation was weighed at the time and corrections then carried out for volumetric differences between spits (see Table 6.2). There are major variations in the patterning and rate of discard of ceramics between spits and through time that are not obviously attributable to the nature of vessel parts represented, e.g. heavy bases or sago ovens versus walls of thinner vessels. Similar variations in the quantity of economic shellfish discarded through time were also noted (see Table 6.3).

While acknowledging the small size of the excavation this variability does suggest that different patterns of occupation and discard have obtained through time on at least this portion of the site. This stands in contrast to the uniformity in depositional patterns and homogeneity often seen in mono-specific shell mound middens from non-agricultural groups (e.g. Veitch 1996).

The vast majority of fragments are not stylistically diagnostic - coming from the walls of cooking vessels and (likely) water jars. Numerous sub-rounded, cubed fragments appear to be from broken sago ovens, and their degree of breakage suggests they may have served a subsequent function as heat retainers in open hearth fires. The assumed sago oven fragments occur only in the upper 12 spits. They thus all post-date Wk-6097 calibrated to $644-307 \mathrm{BP}$, and may suggest a post-European contact date for the introduction of clay sago moulds to Aru.

Decorated pottery fragments were present in small numbers throughout the site in Spits 2, 4, $7,8,14,15,16,17,18,22$, and 26 (Table 6.2) and are discussed and illustrated below.

The variety of gastropods and bivalves represented in Table 6.3 illustrates exploitation of a wide variety of habitats including littoral sand and mudflats, coral reef/shallow water embayments, and mangrove mudflat systems. All habitats are located within several hundred metres of the site.

Most shellfish species are registered in all six layers, although only in very small weights and in highly fragmented form in the lower two. The highest figures for NISP and weights in most species were obtained from layers one and three. Tridacna sp. typically occurs in very low numbers, usually being processed and discarded on reef flats while the Lambis lambis shows typical breakage patterns created from the extraction of flesh after roasting (cf. Bird et al. 2002). 
Table 6.3 Wangil Midden: number of individual specimens identified (NISP), and weight (g) by spit for economic shell species recovered from the test excavation

\begin{tabular}{|c|c|c|c|c|c|c|c|c|c|c|c|c|c|c|c|c|}
\hline \multirow[t]{2}{*}{ SPITS } & \multicolumn{2}{|c|}{$\begin{array}{l}\text { ANADARA } \\
\text { GRANOSA }\end{array}$} & \multicolumn{2}{|c|}{$\begin{array}{l}\text { GELOINA } \\
\text { COAXANS }\end{array}$} & \multicolumn{2}{|c|}{$\begin{array}{c}\text { TEREBRALIA } \\
\text { PALUSTRIS }\end{array}$} & \multicolumn{2}{|c|}{$\begin{array}{l}\text { LAMBIS } \\
\text { LAMBIS }\end{array}$} & \multicolumn{2}{|c|}{$\begin{array}{l}\text { TELESCOPIUM } \\
\text { TELESCOPIUM }\end{array}$} & \multicolumn{2}{|c|}{$\begin{array}{c}\text { ANADARA } \\
\text { TRAPEZIA }\end{array}$} & \multicolumn{2}{|c|}{$\begin{array}{c}\text { TRIDACNA } \\
\text { SP. }\end{array}$} & \multirow{2}{*}{$\begin{array}{c}\text { ANADARA } \\
\text { FRAGMENTS } \\
9\end{array}$} & \multirow{2}{*}{$\begin{array}{c}\text { OTHER } \\
\text { FRAGMENTS } \\
9\end{array}$} \\
\hline & NISP & $g$ & NISP & $g$ & NISP & $g$ & NISP & $g$ & NISP & $g$ & NISP & 9 & NISP & 9 & & \\
\hline 1 & 125 & 1190 & 18 & 100 & 9 & 25 & 7 & 260 & 15 & 180 & 14 & 55 & 0 & 0 & 65 & 530 \\
\hline 2 & 370 & 3410 & 44 & 250 & 33 & 180 & 3 & 100 & 48 & 700 & 22 & 95 & 1 & 110 & 100 & 1370 \\
\hline 3 & 90 & 680 & 29 & 200 & 32 & 125 & 3 & 150 & 27 & 500 & 7 & 25 & 2 & 100 & 80 & 370 \\
\hline 4 & 40 & 215 & 7 & 50 & 13 & 45 & 2 & 140 & 17 & 240 & 11 & 120 & 0 & 0 & 10 & 300 \\
\hline 5 & 3 & 15 & 1 & 10 & 1 & 5 & 1 & 20 & 6 & 25 & 1 & 10 & 0 & 0 & 0 & 40 \\
\hline 6 & 4 & 20 & 4 & 15 & 6 & 15 & 0 & 0 & 3 & 10 & 5 & 15 & 0 & 0 & 10 & 25 \\
\hline 7 & 24 & 24 & 4 & 50 & 3 & 10 & 3 & 60 & 4 & 50 & 11 & 80 & 0 & 0 & 5 & 180 \\
\hline 8 & 3 & 15 & 5 & 25 & 4 & 15 & 0 & 0 & 3 & 25 & 9 & 25 & 0 & 0 & 5 & 15 \\
\hline 9 & 2 & 10 & 2 & 10 & 0 & 0 & 0 & 0 & 3 & 25 & 3 & 10 & 0 & 0 & 0 & 90 \\
\hline 10 & 10 & 50 & 4 & 15 & 3 & 10 & 1 & 10 & 2 & 10 & 5 & 20 & 0 & 0 & 5 & 420 \\
\hline 11 & 12 & 75 & 0 & 0 & 0 & 0 & 0 & 0 & 3 & 25 & 7 & 50 & 0 & 0 & 0 & 180 \\
\hline 12 & 12 & 100 & 0 & 0 & 0 & 0 & 0 & 0 & 7 & 40 & 5 & 20 & 1 & 60 & 5 & 240 \\
\hline 13 & 64 & 340 & 29 & 150 & 11 & 25 & 0 & 0 & 26 & 260 & 8 & 80 & 2 & 10 & 10 & 570 \\
\hline 14 & 150 & 1090 & 37 & 230 & 25 & 110 & 7 & 150 & 42 & 650 & 22 & 130 & 0 & 0 & 155 & 1850 \\
\hline 15 & 111 & 770 & 13 & 95 & 13 & 55 & 5 & 140 & 28 & 270 & 25 & 140 & 0 & 0 & 10 & 710 \\
\hline 16 & 235 & 1820 & 41 & 350 & 53 & 240 & 9 & 280 & 46 & 680 & 54 & 380 & 0 & 0 & 100 & 1520 \\
\hline 17 & 129 & 940 & 44 & 300 & 29 & 220 & 4 & 110 & 60 & 400 & 53 & 360 & 2 & 25 & 130 & 690 \\
\hline 18 & 51 & 340 & 10 & 90 & 9 & 50 & 4 & 90 & 12 & 150 & 28 & 230 & 1 & 220 & 50 & 390 \\
\hline 19 & 21 & 120 & 3 & 15 & 10 & 75 & 0 & 0 & 7 & 90 & 14 & 140 & 0 & 0 & 5 & 90 \\
\hline 20 & 35 & 260 & 7 & 60 & 36 & 200 & 3 & 50 & 7 & 25 & 18 & 220 & 0 & 0 & 20 & 250 \\
\hline 21 & 11 & 50 & 0 & 0 & 9 & 30 & 2 & 50 & 5 & 60 & 4 & 40 & 0 & 0 & 50 & 60 \\
\hline 22 & 5 & 50 & 1 & 5 & 2 & 10 & 1 & 20 & 4 & 20 & 9 & 25 & 0 & 0 & 10 & 50 \\
\hline 23 & & Only ne & e we & hts & гесо & orded f & hellfi & fro & is spi & and $b$ & & & & & & \\
\hline
\end{tabular}

Fluctuations in the density of the different species through time in the six layers are broadly consistent between each other (and the pottery weights) and are likely to reflect levels of activity rather than changes in habitat or other environmental factors. There is a clear deterioration in the condition of shellfish in Layers 5 and 6 with all but the most robust portions being heavily etched and having a moist and friable appearance. This seems likely to be due to the effect of water movement causing dissolution of the shell in this lower part of the site.

\section{Description of the Decorated Pottery Assemblage}

We have illustrated the majority of decorated sherds from the test pit excavation at Wangil and from the nearby disturbed sand quarry area so that future research will be able to fit them into a more definite schema (Figs 6.11-6.15). Although the material from the test pit dates to the last millennium, this is not necessarily the case with the sample from the quarry area. It could be somewhat earlier and is considered separately below.

Within the Aru group, comparison is only possible with the Nabulei Lisa pottery assemblage. Aside from the semi-complete broken vessels collected from the surface (see Chapter 7, Figs 7.26-7.28), the Nabulei Lisa pottery consisted of a small number of undecorated and largely undiagnostic sherds confined to the top eight spits, to a depth of approximately $18 \mathrm{~cm}$. Based on the dates from Spit 5 of $780 \pm 50$ (ANU-1092), Spit 10 of Modern (ANU-10919), and Spit 11 of 2530 \pm 60 (OZF249), it is assumed that the pottery in Nabulei Lisa all dates to the last 1000 years (see Chapter 7, this volume). The maximum number of sherds in any single spit was eight — in Spit 1. Only three small, undiagnostic, earthenware sherds were recovered from Test Pit $\mathrm{C}$ at Liang Lemdubu, all from the upper two spits. 
Sherds from the Wangil test pit comprised several vessel types. Fragments of clay sago ovens were the most easily identifiable, and were recovered from the upper 12 spits. There were also unrestricted vessels that were probably cooking pots or sago paste (pepeda) bowls. Restricted orifice vessels, sometimes carinated, were also probably used for cooking but the presence of flat bases and handles in the uppermost spit might suggest some functioned as water storage jars. There was also a shallow bowl - or more likely a lid - with curvilinear incision, two parallel incised lines bordering punctation, and a post-firing drill-hole (WM-22-3; Figs 6.14, 6.15). Imported Chinese ceramics made up the rest of the collection.

Most of the decoration consists of linear and curvilinear incision, simple rectilinear motifs being less common. Decoration generally occurs just below the rim and above the carination or change of direction where this is present. One rim of a restricted vessel from Spit 22 (WM-222) has what seems to be an applied 'collar' around the restriction, and a distinctive scalloped and partly notched lip (Figs 6.14, 6.15). There are two other examples of notching on the lip from Spit 26 (WM-26-1 and WM-26-1, Fig. 6.14), the remainder of the rim sherds being plain. The absence of lip notching in the upper spits of the site may purely be a question of sample size. Merton's 1907-08 description of pottery manufacture at Maikoor (quoted above) and our own observations at Batu Lei in 1996, showed that lip notching has certainly been practiced over the past 100 years. A single sherd from Spit 16 has a probable suspension hole through an applied band, but its orientation is unclear. Several other sherds have holes bored through them, again possibly for suspension. A plain rim, red-slipped bowl form, also from Spit 16, has an applied notched band along the carination, 3-4cm below the lip (WM-16-1, Fig. 6.13). The only other piece with applied decoration (from Spit 2) has a plain external ridge added of a form found in central Moluccan late prehistoric pottery and known as a 'ridge-rim' (Spriggs 1990). One red-slipped neck sherd has fingernail impressions along the exterior corner point (WM-17-2, Fig. 6.14), and one carinated sherd from Spit 18 has a row of 'stick' or single tool impressions above the carination (WM-18-1, Fig. 6.14). Several incised sherds have impressed dots or punctation as part of the design (see Figs 6.13, 6.14). There seems to be no relation between sherd thickness and type of decoration. Sherds of two vessels of very different thickness - one from Spit 7 and the other from Spit 22 - bear very similar complex incised motifs. There is nothing in the vessel forms or 


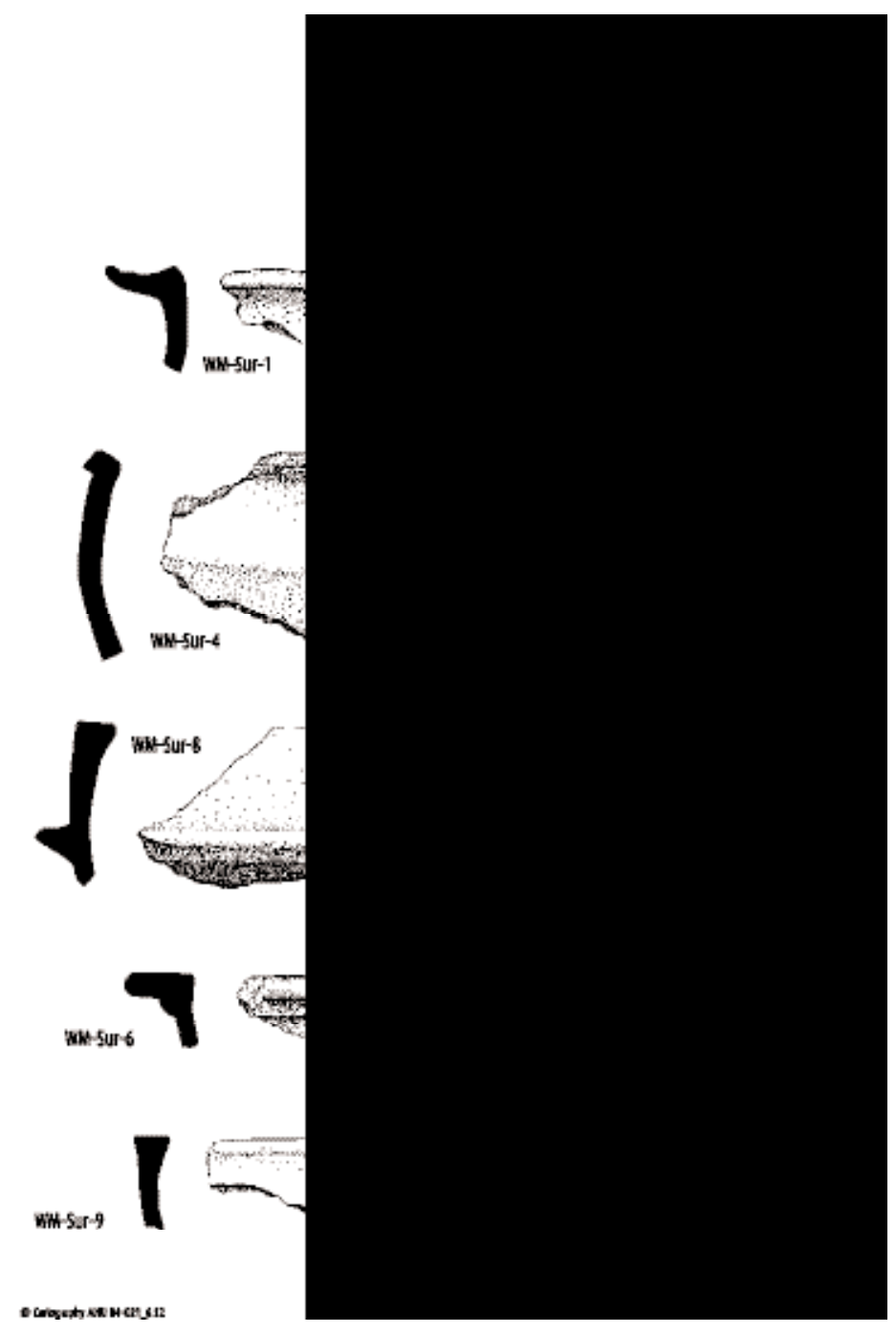

Figure 6.12 Wangil Midden: diagnostic and decorated pottery sherds among the surface collection, including rims from restricted neck vessels (WM-Sur-3, WM-Sur-1); a rim from a restricted bowl and a body sherd with ridged flanges (WM-Sur-2, WM-Sur-8); a necked shoulder from an everted globular pot (WM-Sur-4); part of a flat-based vessel (WM-Sur5); rims from plain and carinated open bowls (WM-Sur-7, WM-Sur-10); a parallel rim with raised ridge (WM-Sur-6); and two rims from restricted bowls (WM-Sur-9, WM-Sur-11 - the latter with raised ridges) (see Table 6.4 for details) decoration to suggest anything other than a relatively recent age for their production. Red-slipped pottery is mainly found in the surface deposits at Wangil, including the disturbed quarry site, but two red-slipped pieces (WM-17-1 and WM-22-1) were also recovered from Spits 17 and 22 of the excavation (Figs 6.14, 6.15).

One potentially distorting factor in any discussion of Aru pottery decoration is that we do not know how long the painted decoration on the modern pottery of the group could be expected to last once buried or exposed on the surface. Observations in 1975 by Spriggs of surface-collected pottery from the Kei Islands, suggested that the painted decoration ubiquitous on modern pottery there does not last long once exposed following breakage and discard. Conditions in the Aru Islands might be comparable and so many plain sherds excavated at Wangil or other sites, or those that display only lip notching, may have once been painted. The painted decoration on the Nabulei Lisa pottery is only apparent on the sherds recovered from the surface. With the exception of painted decoration, however, the pottery from the excavation looks very similar to that from the surface (in terms of temper and vessel form), so it seems likely that painted decoration simply does not survive burial. This is obviously an issue that needs further research.

The sherds from the sand quarry area, as mentioned earlier, included some red-slipped vessels which superficially resemble some from the Neolithic and Early Metal Age assemblages elsewhere in Eastern Indonesia. If we compare them with the material from the test pit, there is certainly the possibility that they date to a period earlier than the last millennium.

The diagnostic sherds from Nabulei Lisa are illustrated and discussed in Chapter 7. Vessel forms included a series of restricted orifice cooking pots, usually with plain lips and lacking incised decoration on the body. The collar form was distinctive and different from the Wangil examples. Some strongly restricted orifice vessels were most probably water jars, one of which was decorated with a complex rectilinear painted design in red. This resembles ethnographically recorded decoration. The larger size of several surface sherds at Nabulei Lisa makes it easier to reconstruct vessel form and this inhibits direct comparisons with Wangil. Clearly, however, the curvilinear 
incised decoration favoured at Wangil in the last thousand years is missing at Nabulei Lisa. This might imply temporal differences - with a general tendency in Island Southeast Asia for pottery to become more highly decorated over time - but it might also represent stylistic differences between pottery production centres in the Aru group, or simply be due to a more limited range of pottery vessels being employed in the cave site. Nabulei Lisa is much closer to Batu Lei than to Samang or Maikoor, and so its pottery probably comes from a different source than that at Wangil.

Most of the pottery at Nabulei Lisa, both from the surface and from the excavation resembles the Batu Lei pottery in having a coarse calcareous and quartz sand temper, and in being low fired. In contrast, the Wangil decorated pottery is much more variable in the vessel form, types of decoration, and fabric composition. The difference is likely to reflect the different site types which we have sampled. Nabulei Lisa is a cave site and while close to the sungai it was probably used predominantly as a hunting or stop over camp whilst visiting gardens. It is not likely therefore to have the range in pottery vessels that one might expect at a village site on the coast.

Initial separation into different fabric groups was accomplished using a binocular microscope at low level magnification $(\times 10)$ and aimed at discriminating the maximum number of 'potential types'. This megascopic examination discriminated nine potential temper types. Examples from each type group were then sent for petrographic analysis to Prof. William Dickinson at the University of Arizona (see Appendix 6.1 for his full description). After further megascopic examination, Dickinson selected 25 sherds comprising examples of each of the temper types from Wangil and Nabulei Lisa for detailed petrographic analysis, and these were compared against each other and with temper and clay samples collected from the modern pottery making center at Batu Lei. Eighteen sherds were examined from Wangil. Dickinson concluded that all of the Nabulei Lisa sherds (described in Chaper 7, this volume), and nine of the Wangil sherds, are quartz-calcite tempers that are generically similar to the Batu Lei sand 

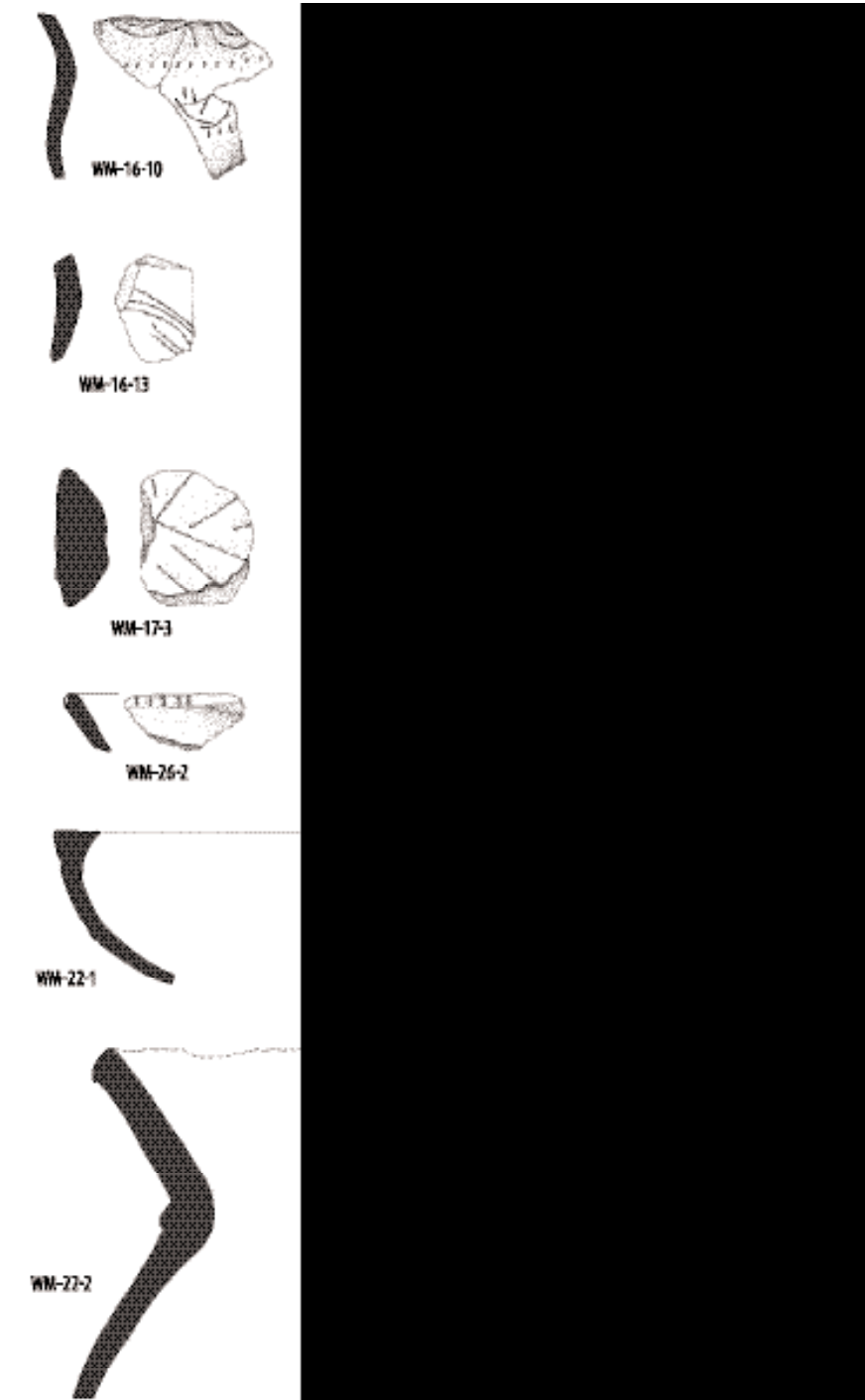

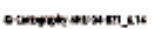

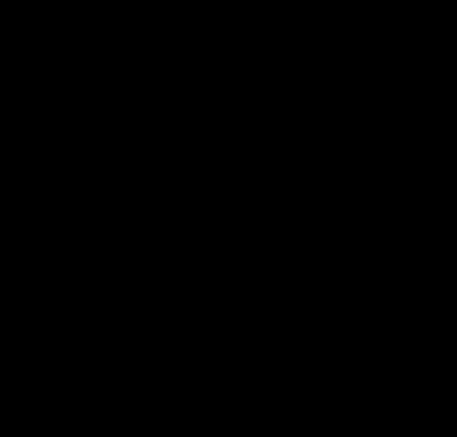

Figure 6.14 Wangil Midden: decorated pottery from Spit 22 of the excavation, including techniques such as linear and curvilinear incision on neck and body sherds and a carination (WM-16-11, WM-16-12, WM16-13, WM-17-1, WM-17-3); linear and curvilinear incision with punctation (WM-16-10); linear incision with fingernail impressions (WM17-2); single tool impressions (WM-18-1); linear incised lip notching (WM-26-1, WM-26-2); linear and curvilinear incision with punctation and a drilled hole (WM-22-3); grooves (WM-22-1); and a scalloped and incised lip (WM-22-2) (see Table 6.4 for details) (megascopic temper groups 1-5) and are almost certainly indigenous to Aru (WRD-212). The quartz-calcite ratio varies, as does the temper texture, but Dickinson believes it is unlikely that the variations are geologically very significant. Six of the Wangil quartzcalcite tempered sherds contained a much siltier paste than the Nabulei Lisa specimens, indicating that the two related ceramic suites were not identical. In addition, the Wangil sample contained eight sherds, including three with red-slip, that were very different, having a volcanic sand temper and a paste that could not be derived from the Aru Islands (megascopic temper groups 6, 8 and 9). With the exception of the red-slipped sherd from Spit 22, the exotic specimens were all from the surface of the Wangil test pit. Dickinson compared the exotic Aru temper with sherds from Halmahera and Banda (WRD-237, -238, -220) and found that while some of the Halmahera tempers were mineralogically similar to the exotic Aru sherds, some of the Banda tempers were 'visually identical texturally and statistically indistinguishable mineralogically from tempers in the exotic Aru sherds'. The 'pastes in the Banda sherds also contain vitroclastic glass shards of volcanic ash that are indistinguishable from those in the pastes of exotic Aru sherds'.

Dickinson concludes that the combined petrographic match of temper and paste between indigenous Banda sherds and exotic Aru sherds leaves no reasonable doubt that the exotic Aru sherds derive from wares brought to Aru from Banda, and not from Halmahera (Appendix 6.1, WRD-238).

A single sherd collected from the surface of Wangil, WM-Sur-5 (megascopic temper type 7; WRD-212), contained an unusual subangular quartz-feldspar sand temper. Dickinson concludes that this temper is not related to either the 'indigenous quartz-calcite temper' group or the 'exotic volcanic sand temper' group. He suggests that this temper is unlike the other Aru sherds in that it almost certainly derives from an imported ware, but its origin is indeterminate. Dickinson's full reports on the Aru, Halmahera and Banda sherds are contained in Appendix 6.1. 


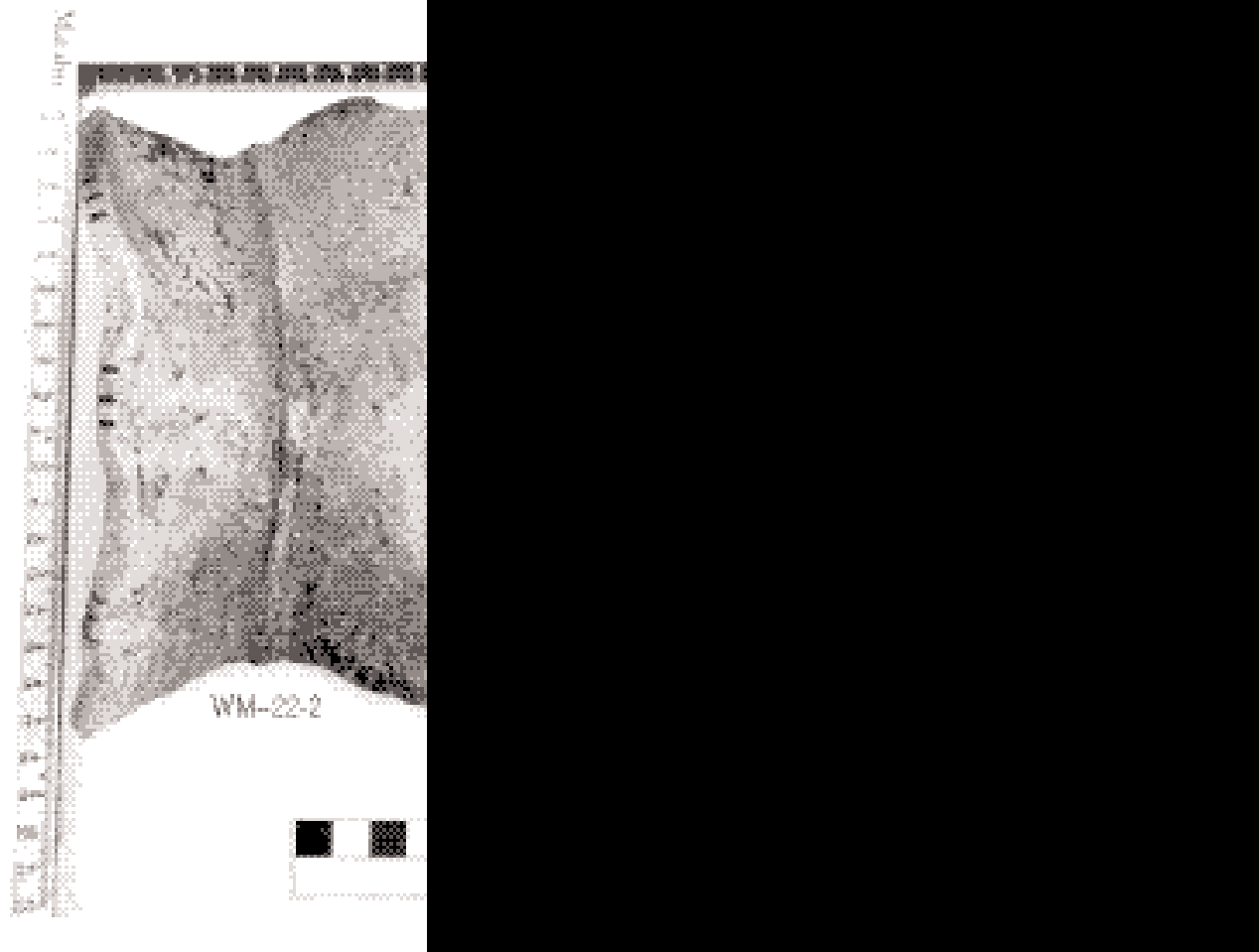

Figure 6.15 Wangil Midden: decorated pottery sherds from the excavation, including the fragment of an everted globular pot with a scalloped and incised lip (WM-22-2); the red-slipped open bowl fragment with exterior grooves (WM-22-1); and the possible lid fragment with linear and curvilinear incision, punctation, and a drilled hole (WM-22-3) (see illustrated sherds and Table 6.4 for details)

Wider stylistic comparisons of the Wangil test pit material did not prove enlightening. We have reviewed all the published material on surface-collected pottery, or that dated to the last 2000 years from Maluku, Timor, Papua (former Irian Jaya) and Sulawesi - the references are too numerous to list here - and can find no close parallels to the incised decoration other than in rectilinear motifs so simple as to be almost ubiquitous. This is of course to be expected for this time period in the region, as discussed by Pétrequin and Pétrequin (1999:73-4). First of all they note the presence of a number of different methods to produce what is basically the same vessel type, but which on typological grounds might be divided into several stylistic 'provinces' based on variants in form. They note that if the same typologist used a detailed comparison of pottery decoration the number of small stylistic provinces would grow: virtually every production area possesses specific decorative techniques and processes which allow one, usually at first glance, to differentiate each production centre from its neighbours' (translation by Spriggs).

The painted designs on ethnographic pottery from Aru, however, would clearly bear comparison with that from the neighbouring island group of Kei, and more distantly with the painted pottery of Timor (see Pétrequin and Pétrequin 1999:fig. 6), but such a comparison is beyond the scope of this study. The time depth of painted decoration on Aru, Kei and Timor pottery is itself unknown, at least in part because of the taphonomic problems of paint preservation on sherds over time referred to above.

The technological study by the Pétrequins suggests that the current pottery manufacturing techniques in Kei, Aru and Timor represent the diffusion of techniques from further west during the Metal Age of the early first millennium AD (1999:fig.17c). The current dates available for pottery in the Aru Islands, discussed above, do not contradict this suggestion. Their idea of further diffusion of pottery technology perhaps from Aru itself into the Papuan Gulf of present-day Papua 


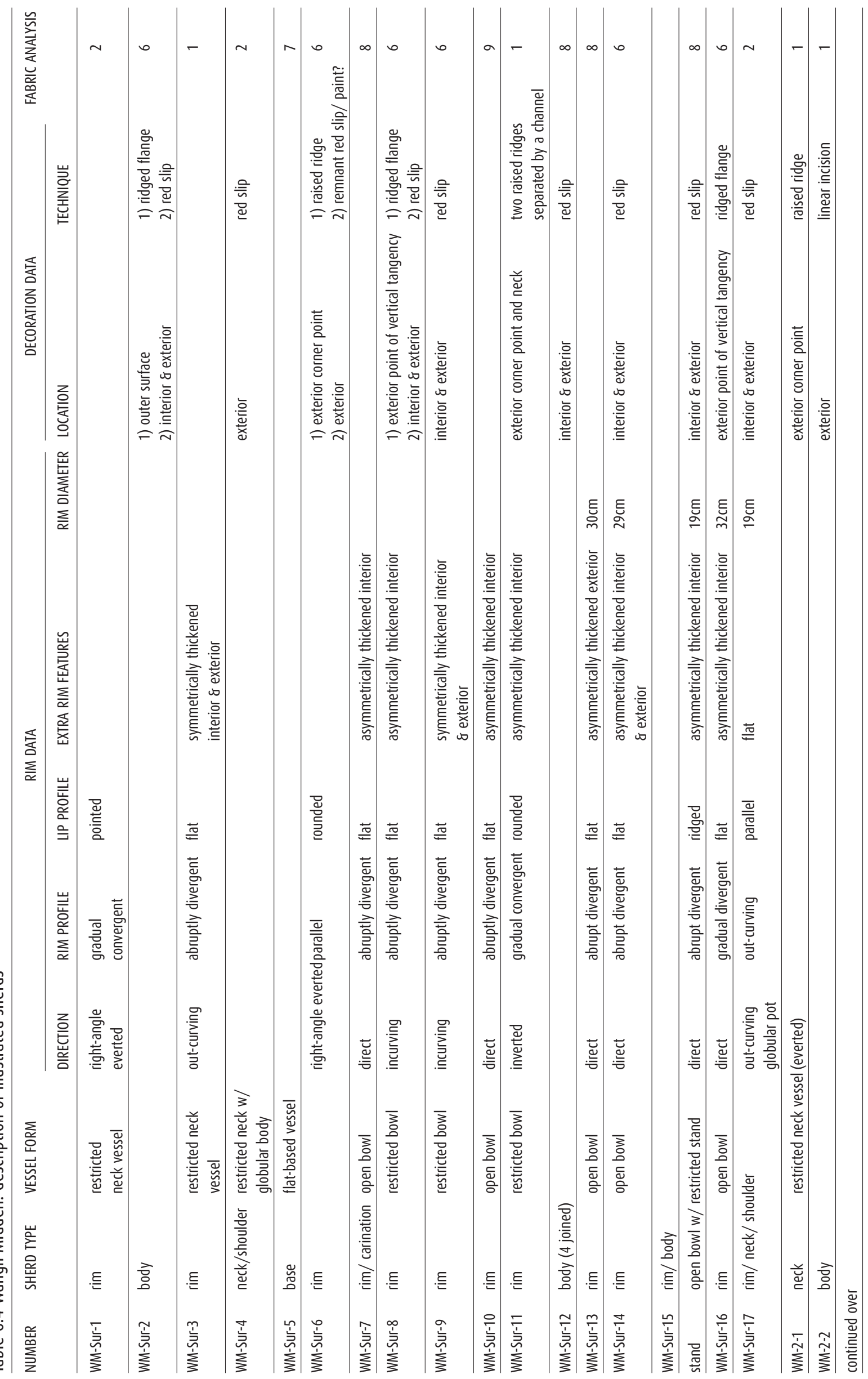




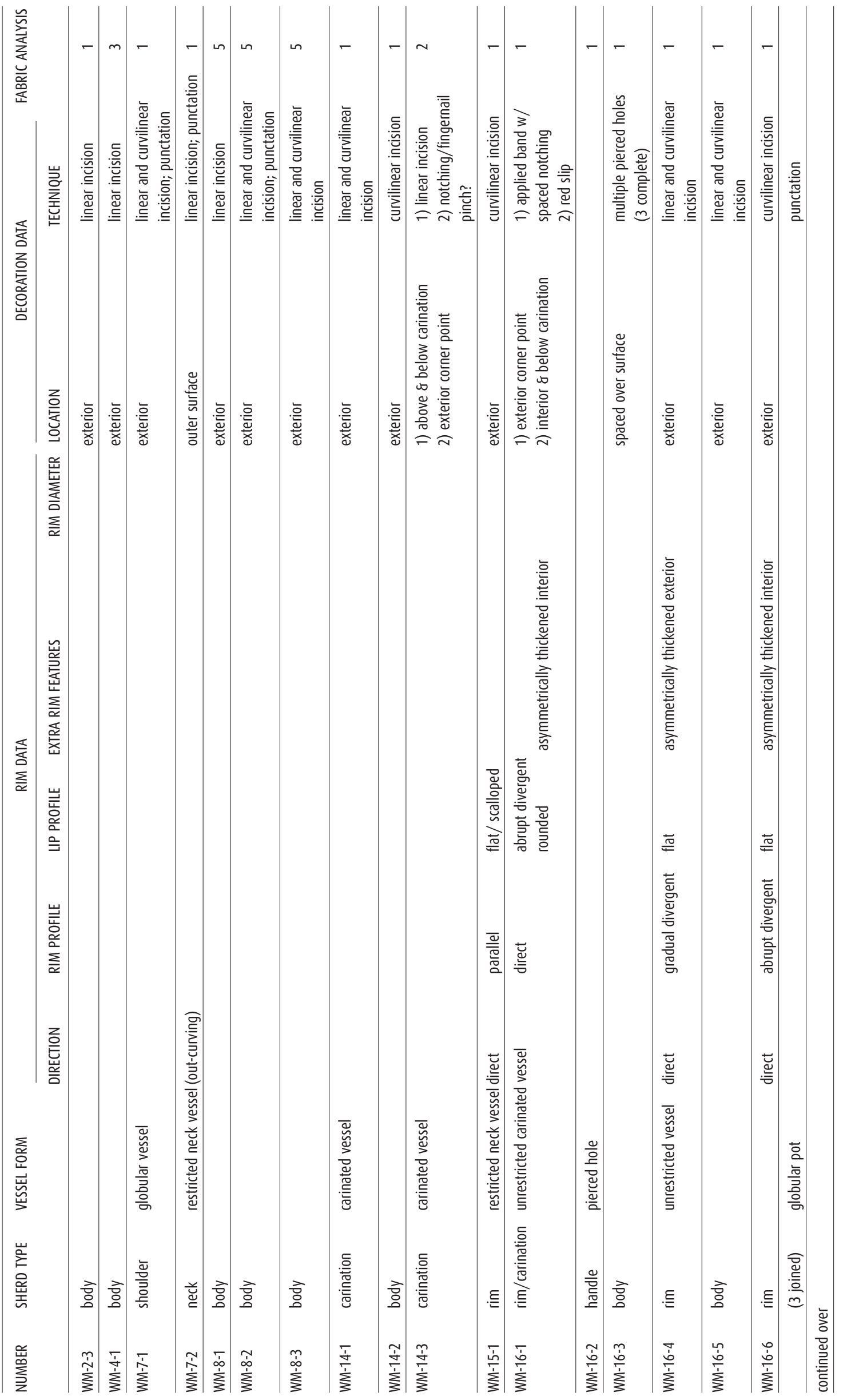




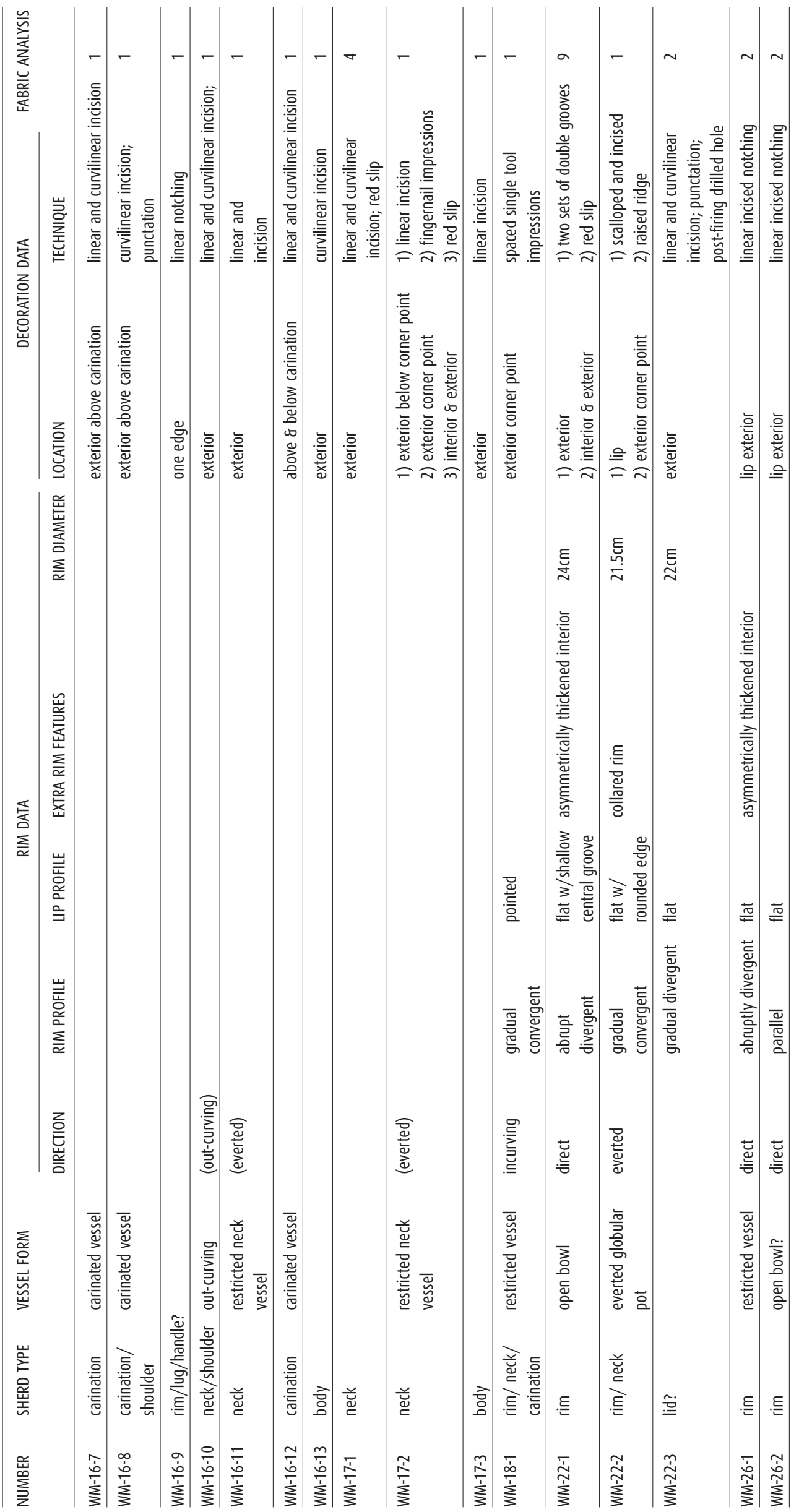


New Guinea (Yule Island and the Port Moresby region) is even more speculative, but is supported by some other lines of evidence indicating connections between the two regions over the last several hundred years at least (discussed in Chapter 1), related to the birds of paradise trade. Detailed technological studies of Aru and other archaeological pottery assemblages to identify details of manufacturing techniques will be required for the ideas of the Pétrequins to be given any more than speculative time depth. Will the earliest pottery of the region turn out to have been constructed using quite different potting techniques as their model would seem to require? Their suggestion is that, given the difficulty of learning the particular techniques now practiced in Aru and the other areas mentioned — which are unlikely to be acquired by simple imitation - a direct migration of potters from further west in Indonesia would be required (1999:97).

\section{Interpretation of the Sequence Within the Aru Islands}

The Wangil midden is an extensive mounded structure perched on an isthmus, flanked by marine coast on one side and a sago swamp formed within a palaeolagoon on the other. Large volumes of marine shellfish attest to systematic exploitation of a variety of proximal habitats including coral reef and flats, sand and mudflats, and mangroves.

Substantial volumes of pottery occur on the site with a minor component consisting of decorated ware. Historical and ethnographic accounts document several centres of pottery production in the Aru group, the closest being Samang on Pulau Wokam to the north. Fragments of broken sago ovens were extremely common on the site, most likely reflecting the importance of this staple food, the proximity of sago stands, and the likely role of this product as an export from the Aru Islands in supporting the forced labourers of the Banda spice production centre (Spyer 2000; Veth et al. 2000; Chapter 5, this volume). This trade relationship receives substantive support from the analysis of the red-slipped and other earthenware sherds in the Wangil midden which contained an exotic volcanic temper and paste. Dickinson's analysis, discussed above, leaves no doubt that these sherds derive from wares brought from Banda to Aru. Although most of the exotic sherds were from the surface, one was obtained from Spit 22, attesting to the longevity of this relationship over the last 700 years. Historically, Wangil was noted to be one of the largest villages on the west coast with an early Dutch garrison established there in the course of the 17th century (see Chapter 5, this volume).

Dates from the test pit illustrate occupation during the last millenium with the majority of decorated ware bracketed by dates of approximately $800 \mathrm{BP}$ and $300 \mathrm{BP}$, at the extremes. The Wangil pottery is consistent with the regional ethnographic pattern that displays great variability of decoration within a few major production traditions (cf. Pétrequin and Pétrequin 1999:73-4). The site is used for gardening today and also the casual processing and discard of a limited range of shellfish. There are no obvious changes in the proportions or species of economic shellfish through time to suggest major changes in the use of the site or local habitats over the last millennium. During three seasons of survey and recording, the most common midden forms encountered are buried linear middens often situated near historic village sites, such as at Wangil. Where older shorelines have been augered and middens detected, such as in front of the Fany Hotel in the nearby town of Dobo, they are likely to be mid-late Holocene in age, although no dates have been obtained to verify this (see Chapter 4 , this volume). This pattern is very likely to be a product of various factors, among which is certainly sampling. Other important factors could be coastal progradation, poor preservation on coarse sands due to leaching in the tropical climate, and the combined cultural effects of gardening and mining for lime. 


\section{References}

Bird, D.W., J.L. Richardson, P. Veth, and A. Barham. 2002. Explaining shellfishing variability in middens on the Meriam Islands, Torres Strait, Australia. Journal of Archaeological Science 29:457-69.

Bellwood, P. 1997. Prehistory of the Indo-Malaysian Archipelago. Honolulu: University of Hawai'i Press.

Ellen, R.F. and I.C. Glover. 1974. Pottery manufacture and trade in the Central Moluccas, Indonesia: the modern situation and the historical implications. Man (N.S.) 9:353-79.

Gasser, S.A. 1969. Das Töpferhandwerk von Indonesien. Basler Beitrage Ethnologie 7. Basel: Pharos-Verlag, Hans Rudolph Schwabe.

Merton, H. 1910. Forschungsreise in den Sudostlichen Molukken (Aru-und Kei Inslen). Frankfurt, A.M.: Senckenbergischen Naturforschenden Gesellschaft. English translation by A. and A. Veth (1998), James Cook University, Townsville.

Pétrequin, P. and A.M. Pétrequin. 1999. La poterie en Nouvelle-Guinée: savoir-faire et transmission des techniques. Journal de la Société des Océanistes 108:71-101.

Spriggs, M. 1990. Archaeological and ethnoarchaeological research in Maluku 1975 and 1977: an unfinished story. Cakalele: Maluku Studies Research Journal. 1(1-2):51-65.

Spriggs, M. 1998. Research questions in Maluku archaeology. Cakalele: Maluku Studies Research Journal 9(2):49-62.

Spyer, P. 2000. The Memory of Trade: Modernity's Entanglements on an Eastern Indonesian Island. Durham: Duke University Press.

Veitch, B. 1996. Evidence for mid-Holocene change in the Mitchell Plateau, Northwest Kimberley, Western Australia. In P. Veth and P. Hiscock (eds), Archaeology of Northern Australia: Regional Perspectives, pp. 66-89. St Lucia: Anthropology Museum of the University of Queensland. Tempus 4.

Veth, P., S. O'Connor, M. Spriggs, D. Witjaksono, and A. Diniasti. 2000. The mystery of the Ujir Site: insights into early historic settlement in the Aru Islands, Maluku. The Bulletin of the Australian Institute for Maritime Archaeology 24:125-32. 


\title{
Appendix 6.1: Petrography of Temper Sands in Prehistoric Potsherds from the Aru Islands, South of West Irian Near the Shelf Edge of the Arafura Sea
}

\author{
William R. Dickinson \\ Petrographic Report WRD-212 ( 23 April 2002)
}

From a collection of prehistoric potsherds from the Aru Islands sent for study by Sue O'Connor of the Australian National University, 25 were examined petrographically in thin section. The sherds derive from the Nabulei Lisa cave site (sherd prefix NL-) on Aru and the Wangil mounded midden site (sherd prefix WM-) on Wammar.

The Aru ceramic suite includes sherds containing three distinct kinds of temper:

1) quartz-calcite temper $(\mathrm{n}=16)$ inferred to be indigenous to the Aru Islands;

2) volcanic sand temper $(\mathrm{n}=8)$ inferred to be exotic to the Aru Islands; and

3) quartz-feldspar temper $(\mathrm{n}=1)$ in one anomalous sherd (WM-Su-5).

The exotic temper is imbedded in an unusual ash-rich paste, and occurs only in sherds judged typologically to be imports to the Aru Islands from elsewhere, probably Indonesian islands lying farther west.

\section{Geologic Setting}

The Aru Islands lie near the shelf edge of the Arafura Sea south of West Irian, and expose only Neogene marine shelf strata deposited in shallow water (Hamilton 1979). As the Aru Islands are part of the Australia-New Guinea continental block, which formed the contiguous Sahul landmass during Pleistocene glaciations, Aru sedimentary assemblages are presumably of continental derivation.

\section{Quartz-Calcite Temper}

The majority of the sectioned sherds $(n=16)$ contain generically similar hybrid sand tempers composed of quartz-rich terrigenous detritus mixed with calcareous grains of reef detritus. The sherds include all those grouped megascopically as temper types $1-5$ at both Nabulei Lisa $(n=7)$ and Wangil $(n=9)$. A majority of the Wangil sherds $(n=6)$ contain much siltier paste than any of the Nabulei Lisa sherds, indicating that the two related ceramic suites are not identical. Proportions of terrigenous and calcareous grains vary widely (Table 212-1), but the quartz-calcite aggregates represent the type of sand expected for the Aru Islands. As the more calcareous of the tempers closely resemble the hybrid beach sand used as temper today at Batu Lei in the Aru Islands (Table 212-1), the gradational spectrum of quartz-calcite tempers is interpreted as indigenous to the Aru Islands, and the sherds containing them as local wares. Determination of the quartz/feldspar ratio in the terrigenous fraction of the quartz-calcite tempers awaits the preparation of stained thin sections, but quartz grains appear to be dominant, as expected for sand of ultimately continental derivation.

Table 212-1: approximate relative proportions of calcareous and terrigenous grains in quartz-calcite tempers of indigenous Aru sherds and modern Batu Lei temper sand

A. Calcareous grains predominant, with terrigenous grains rare but present [includes all Wangil (WM-) sherds with silty paste containing quartzose detritus]:

Batu Lei sand, WM-15-1, WM-16-11, WM-16-13, WM-17-1, WM-22-3, WM-Su-17

B. Calcareous grains dominant, but with terrigenous grains present in significant amounts (post-burial leaching has corroded many calcareous grains in WM-Su-1):

NL-A-5C, NL-SU-1, NL-SU-6, NL-SU-11, WM-SU-1

C. Calcareous and terrigenous grains present in subequal proportions (post-burial leaching has corroded many calcareous grains in NL-A-5F and WM-4-1, and removed a significant percentage from WM-4-1):

NL-A-4, NL-A-5B, NL-A-5F, WM-4-1, WM-8-3 
Among the quartz-calcite tempers, there seems no systematic correlation in detail between megascopic temper type and microscopic appearance. Megascopic discrimination among quartzcalcite tempers partly encounters the difficulty that post-burial leaching of calcareous grains from sherds may reduce the apparent ratio of calcareous to terrigenous grains unless the small sandsized vacuoles left after dissolution of calcareous sand grains are correctly identified (Table 212-1). This problem has been encountered irregularly but quite widely in sherd suites studied from both Micronesia and Melanesia. Although ratios of calcareous to terrigenous grains may be significant for understanding the nature of tempers used at different sites within the Aru Islands, confident assessment of local variations will prove difficult for intrinsic geologic reasons as well. For example, all the sectioned sherds with predominantly calcareous tempers derive from Wangil, yet sectioned Wangil sherds also include examples of both classes of more terrigenous quartz-calcite temper (Table 212-1); it is unclear how one might distinguish between local temper variability on Wammar and ceramic transfer from Nabulei Lisa or elsewhere within the Aru Islands.

\section{Volcanic Sand Temper}

Eight sherds (three with red slips) from Wangil [megascopic temper types 6 \& 8-9] contain similar volcanic sand tempers (Table 212-2) wholly different mineralogically from the indigenous quartzcalcite tempers. The pastes in the sherds are also quite different, and to the best of my knowledge are unique among Oceanian sherd suites in containing a high proportion of fresh volcanic glass shards derived from unconsolidated silicic ash deposits. As there is no indication that any volcanic rocks or ash deposits are exposed within the Aru Islands, importation from elsewhere seems assured on the basis of the petrographic character of paste and temper.

The ash particles imbedded in clay paste are isotropic volcanic glass, pale brown or tan to colourless in thin section, with the curvilinear, forked, and branching shapes that are characteristic of glass shards formed by explosive disintegration of vesiculating rhyodacitic or other comparably viscous magmas. In effect, the thin shards represent disrupted vesicle (gas bubble) walls derived from expanding pumice. Proportions of fine ash and clay are difficult to estimate optically, but glass shards consistently appear to form $15 \%-20 \%$ of the clay bodies. This is a significant fraction but evidently not enough to spoil the plasticity of the clay. Although the shards are extremely thin $(<0.05 \mathrm{~mm})$, they reach lengths $\sim 0.25 \mathrm{~mm}$, and their vitroclastic form is unmistakable in thin section.

The occurrence of fresh volcanic glass within a clay body derived from products of rock weathering is difficult to explain. Such intimate mixture of fine ash with clay could probably not be achieved by forcefully kneading ash and clay together without damaging the fragile glass shards,

Table 212-2. Frequency percentages of grain types in volcanic sand tempers of exotic Aru sherds (prefix WM-) based on areal grain counts of $n$ grains in thin section [megascopic temper type in brackets].

\begin{tabular}{|c|c|c|c|c|c|c|c|c|c|}
\hline SHERD $\Rightarrow$ & $\begin{array}{c}\text { SUR-7 } \\
n=155 \\
{[\# 8]}\end{array}$ & $\begin{array}{c}\text { SUR-8 } \\
n=190 \\
{[\# 6]}\end{array}$ & $\begin{array}{c}\text { SUR-9 } \\
n=145 \\
{[\# 6}\end{array}$ & $\begin{array}{c}\text { SUR-10 } \\
n=130 \\
{[\# 9]}\end{array}$ & $\begin{array}{c}\text { SUR-14 } \\
n=80 \\
{[\# 6]}\end{array}$ & $\begin{array}{c}\text { SUR-15 } \\
n=205 \\
{[\# 8]}\end{array}$ & $\begin{array}{c}\text { SUR-16 } \\
n=235 \\
{[\# 6]}\end{array}$ & $\begin{array}{c}22-1^{1} \\
\mathrm{n}=100 \\
{[\# 9]}\end{array}$ & MEAN $^{2}$ \\
\hline \multicolumn{10}{|l|}{ GRN TYPE 3} \\
\hline qtz & $\mathrm{tr}$ & $\mathrm{tr}$ & - & - & - & $\mathrm{tr}$ & - & - & $\mathrm{tr}$ \\
\hline plg & 37 & 33 & 31 & 41 & 36 & 33 & 37 & 42 & $36 \pm 4$ \\
\hline $\operatorname{cpx}$ & 5 & 7 & 4 & 5 & 4 & 6 & 9 & 7 & $6 \pm 2$ \\
\hline ора & 12 & 15 & 22 & 6 & 14 & 4 & 6 & 4 & $10 \pm 6$ \\
\hline gls & 42 & 44 & 40 & 43 & 45 & 52 & 46 & 45 & $45 \pm 3$ \\
\hline mic & 4 & 1 & 3 & 5 & 1 & 5 & 2 & 1 & $3 \pm 2$ \\
\hline
\end{tabular}

1 sherds with visible red slips

2 average and standard deviation

3 qtz, quartz; plg, plagioclase feldspar; cpx, clinopyoxene; opa, opaque iron oxides; gls, vitric (glassy) volcanic rock fragments with vesicular internal structure; mic, microlitic (and rare felsitic) volcanic rock fragments 
but no breakage of the delicately formed shard shapes is evident. Weathered ash, converted partly to clay, is an unlikely source because glass shards should weather at least as readily as any other constituents of volcanic ash. The most likely source is an alluvial deposit in which clayey sediment and reworked fine ash jointly settled quietly from slackwater. The observed intimate admixture of the two disparate components of the paste could not be achieved by sprinkling ash carefully into clay during preparation of the clay bodies because there are no compositional gradients of ash content visible as banding or any other domains of more irregular shape.

Temper sand grains imbedded in the ash-bearing clay pastes contrast markedly in grain size with any paste constituents, and were doubtless added manually to clay bodies. The sands are closely similar and mineralogically simple aggregates (Table 212-2), derived exclusively from volcanic sources, composed mainly of vitric volcanic rock fragments of microvesicular (pumiceous) volcanic glass together with mineral grains of plagioclase feldspar (dominant) and clinopyroxene (subordinate) inferred to derive from sand-sized phenocrysts in the pumiceous volcanic source rock. Evident abrasion of subrounded rock fragments, coupled with lesser abrasion of the harder mineral grains, which tend to be subangular, suggests that the source of the temper was reworked volcanic ash of coarser grain size than the glass shards imbedded in the clay pastes. Both paste and temper could have been derived from different parts or layers of the same reworked ash forming a blanket over the landscape near an active volcano. Generic association of the mineral grains, pumice, and ash is indicated by mineral grains with pumiceous volcanic glass adhering to their edges, and by some pumiceous rock fragments that contain plagioclase microphenocrysts. Varying proportions of opaque iron oxide grains of high specific gravity probably reflect different degrees of sedimentological placering during transport and deposition of the reworked ash. Small numbers of microlitic volcanic rock fragments with tiny microlites of untwinned plagioclase imbedded in volcanic glass may represent detrital contributions from volcanic rocks older than the ash eruptions. Traces of quartz in some of the volcanic sand tempers suggest dacitic rather than andesitic ash, as expected for explosive eruptions.

Grain type frequencies in the volcanic sand tempers are statistically distinguishable only with respect to the variable content of opaque iron oxide grains. Standard deviations of mean grain frequencies (Table 212-2) are otherwise comparable to standard deviations of counting error for the grain populations $(n=80-235)$ present within each sherd. Grain populations visible in each sherd depend partly on the sizes of the sherds and partly on the proportions of temper and paste. A preliminary megascopic temper classification was based partly upon paste color, which is in turn dependent partly on firing conditions and partly on subsequent sherd weathering, and partly upon average sizes of temper grains, which vary but in no systematic way relative to temper compositions. Megascopic temper types 8-9 tend to be more abundant relative to paste, and somewhat coarser grained, with megascopic temper type 6 sparser and finer grained, but sherd WM-Su-16 of the latter group falls microscopically within the former group. In my view, attempts to discriminate among the volcanic sand tempers are unlikely to point to any significant compositional differences, and may simply reflect habits or tastes of individual potters working with the same or closely related raw materials.

\section{Anomalous Temper}

The temper sand (megascopic temper type 7) in sherd WM-Su-5 of unusual appearance is an angular to subangular quartz-feldspar sand, including both plagioclase and K-feldspar, lacking any ferromagnesian grains, but containing a minor proportion of polycrystalline/polyminerallic felsitic to microgranitic lithic fragments probably derived from intrusive igneous rocks. The origin of the temper is indeterminate, but it does not appear to be related to either the indigenous (quartzcalcite) or exotic (volcanic sand) tempers that are prevalent in Aru sherds. Derivation from a continental island is likely, but no specific candidates can be suggested from what is observed in 
just the one sherd. The temper is so unlike those in other Aru sherds that some adventitious introduction to Aru should be entertained as a possibility, but as I am unaware of the occurrence of the sherd, further speculation on my part would be fruitless.

\title{
Temper Sources
}

Beach sands within the Aru Islands appear to represent an adequate and attractive source for the indigenous quartz-calcite tempers, and require no further discussion. There is no firm basis for further discussion of the anomalous temper in one unusual sherd.

Search for the origin of the exotic sherds with ash-bearing paste and volcanic sand temper can be guided by the distribution of active volcanism within Indonesia (Neumann van Padang 1951; Simkin et al. 1968; Hamilton 1978), with special focus on explosive volcanism. The closest volcanic centers lie along the Banda island arc in the Banda Sea to the west of the Aru Islands, but the tiny islands on which they occur are unlikely sites for significant cultural development. Next closest are multiple volcanic centers on Halmahera and nearby smaller islands well to the northwest of the Aru Islands (Hall et al. 1988). The Sangihe island arc (Morrice et al. 1983), extending off the northern arm of Sulawesi across the Molucca Sea to the west of Halmahera is even more distant, and consists of islands as small as those in the Banda Sea.

Essentially all the volcanic centers of Indonesia are dominated by andesitic and basaltic eruptives more mafic than the silicic ash in the exotic Aru sherd pastes, but some explosive dacitic eruptions can be inferred for many of the larger composite stratocones. From that perspective, as well as its position as a large landmass in comparative proximity to the Aru Islands, Halmahera seems the most attractive target to investigate as a potential source for the exotic sherds.

\section{References}

Hall, R., M.G. Audley-Charles, F.T. Banner, S. Hidayat, and S.L. Tobing. 1988. Late Palaeogene-Quaternary geology of Halmahera, eastern Indonesia: initiation of a volcanic arc. Geological Society of London Journal 145:577-90.

Hamilton, W. 1979. Tectonics of the Indonesian region. U.S. Geological Survey Professional Paper 1078:345.

Morrice, M.G., P.A. Jezek, J.B. Gill, D.J. Whitford, and M. Monoarfa. 1983. An introduction to the Sangihe arc: volcanism accompanying arc-arc collision in the Molucca Sea, Indonesia. Journal of Volcanology and Geothermal Research 19:135-65.

Neumann van Padang, M. 1951. Catalogue of the active volcanoes of the world including solfatara fields; Part I, Indonesia, p.271. Napoli: International Volcanological Association.

Simkin, T., L. Siebert, L. McClelland, D. Bridge, C. Newhall, and latter J.H. 1968. Volcanoes of the World, p. 232. Washington (DC): Smithsonian Institution.

\section{Petrography of Additional Aru Sherds}

\author{
Petrographic Report WRD-221 (25 0ct. 2002)
}

Four additional sherds from the Aru Islands were passed to me by Matthew Spriggs in Noumea in August (2002). With reference to my previous report on 25 Aru sherds (Petro Rpt WRD-212), two of the additional sherds appear to be indigenous Aru wares, whereas the other two contain typical exotic temper imbedded in clay paste rich in glass shards of volcanic ash.

\section{Indigenous Sherds}

The two indigenous sherds are 77-1 from Papakulah (thin body sherd with whitened interior surface and pale gray exterior surface with protruding calcareous grains), and 77-2 from Jurlay (thin body sherd with blackened exterior surface and brownish interior surface with scattered visible calcareous grains). Sherd 77-1 contains predominantly calcareous temper (Type A temper of Table 212-1), although quartz silt is present in the clay paste. Sherd 77-2 contains hybrid quartz- 
calcareous temper, with calcareous grains more abundant than quartz (Type B temper of Table 2121). Both these sherds appear to fit within the spectrum of indigenous Aru wares.

\section{Exotic Sherds}

The two exotic sherds, both with red slips that were possibly wiped before firing, are 77-3 from Karkur (rim sherd containing flashing dark ferromagnesian temper grains visible megascopically), and 77-4 from Wangil Midden (rim sherd with hard glossy slip possibly polished after firing). In both (as is the case for the typical exotic Aru sherds examined previously), abundant vitroclastic glass shards of volcanic ash are imbedded in the clay pastes. The frequency counts of temper grain types (Table 221-1) fit within the spectrum of typical Aru exotic wares (Table 212-2).

\section{Summary}

Examination of the four additional Aru sherds confirms the results of my previous study of Aru tempers, and shows that both indigenous and exotic Aru wares are consistently of the same types.

Table 221-1: frequency percentages of grain types in two exotic Aru sherds from Karkur (77-3) and Wangil Midden (77-4) based on areal counts of $n$ grains in thin section; 'previous mean' (Table 212-1) refers to mean composition of eight sherds examined previously (Petro Rpt WRD-212); 'new mean' refers to mean composition of the ten sherds counted to date (Petro Rpt WRD-212 + Petro Rpt WRD-221)

\begin{tabular}{|c|c|c|c|c|}
\hline SHERD fi & $\begin{array}{r}77-3 \\
(\mathrm{n}=222)\end{array}$ & $\begin{array}{r}77-4 \\
(n=211)\end{array}$ & $\begin{array}{r}\text { PREVIOUS MEAN } \\
{[\mathrm{N}=8]}\end{array}$ & $\begin{array}{r}\text { NEW MEAN } \\
{[\mathrm{N}=10]}\end{array}$ \\
\hline \multicolumn{5}{|c|}{ GRAIN TYPE } \\
\hline qtz & tr & $\mathrm{tr}$ & tr & tr \\
\hline plo & 42 & 39 & $36 \pm 4$ & $37 \pm 4$ \\
\hline$c p x$ & 6 & 9 & $6 \pm 2$ & $6 \pm 2$ \\
\hline ора & 8 & 10 & $10 \pm 6$ & $10 \pm 5$ \\
\hline واو & 43 & 40 & $45 \pm 3$ & $44 \pm 3$ \\
\hline mic & 1 & 2 & $3 \pm 2$ & $3 \pm 2$ \\
\hline
\end{tabular}

\section{Evaluation of Aru-Banda Temper and Paste Match}

Petrographic Report WRD-238 (15 June 2004)

Initial petrographic study of Aru sherds (Petro Rpt WRD-212 of 23 April 2003) indicated the presence of an indigenous quartz-calcite temper type (derived from the Aru Islands) in two-thirds of the sherds examined in thin section, but also of an exotic volcanic sand temper type (derived from elsewhere) in the other one-third of the sherds examined. The exotic sherds contain tiny vitroclastic shards of volcanic glass (eruptive ash) imbedded in the clay pastes. This distinctive paste constituent had not previously been detected in any other Oceanian sherd suites. Further study of an additional four Aru sherds revealed the same two types of temper and paste in two sherds each (Petro Rpt WRD-221 of 25 Oct. 2003).

A search for the origin of the exotic Aru sherds led to examination of five sherds from Halmahera (Petro Rpt WRD-220 of 17 July 2003 as revised 15 June 2004). One of the Halmahera sherds, from Pulau Kumo, proved to contain vitroclastic ash in its paste. Moreover, the Pulau Kumo temper, although much finer grained than the tempers in exotic Aru sherds, has a mineralogical composition closely comparable to the latter. These fortuitous similarities suggested the hypothesis that the exotic Aru sherds may have come from somewhere in northern Halmahera.

Subsequently, however, examination of sherds from Banda (Petro Rpt WRD-237 of 15 June $2004)$ indicates that selected Banda tempers $(n=4)$ are visually identical texturally and statistically indistinguishable mineralogically from tempers in the exotic Aru sherds. Pastes in the Banda 
sherds also contain vitroclastic glass shards of volcanic ash that are indistinguishable from those in the pastes of exotic Aru sherds.

The combined petrographic match of temper and paste between indigenous Banda sherds and exotic Aru sherds leaves no reasonable doubt that the exotic Aru sherds derive from wares brought to Aru from Banda, and not from Halmahera. The suggestive similarities between Aru sherds and the Pulau Kumo sherd from Halmahera carry little or no weight in the face of the conclusive and combined temper-paste matches between Aru and Banda sherds.

The search for the origin of the exotic Aru sherds, including erroneous consideration of Halmahera as a possibility for a year or so, is an apt reminder that only exact temper matches constitute robust evidence for ceramic transfer from one island to another.

\section{Comparison of Aru and Halmahera Sherds}

Petrographic Report WRD-220 (17 July 2002)[Revised 15 June 2004]

In an effort to trace the possible origin of exotic Aru sherds (Petro Rpt WRD-212), Sue O'Connor sent me five sherds (numbered by me as 74-1 thru 74-5) collected by Peter Bellwood on Halmahera and neighboring islets:

74-1 \& 74-2: Makian Island west of Halmahera

74-3: Vattandi on Kayoa Island west of Halmahera

74-4: Pulau Kumo near Tobele on north Halmahera

74-5: Umera Island (?) near Halmahera

I cannot locate either Kayoa or Umera on any maps available to me, but Makian is an active volcano (six historic eruptions, AD 1646-1890) of the Quaternary Halmahera volcanic arc. I presume that Pulau Kumo and Tobele are on the north arm of Halmahera where the Halmahera arc (several active volcanoes including major edifices at Dukono, Ibu, Gamkonora from north to south) extends to the north of the offshore volcanic islands lying west of Halmahera (including Ternate, Tidore, Makian from north to south).

Tempers in the sherds from the offshore islands $(74-1,2,3,5)$ are volcanic sands, well sorted and variably abraded, of probable beach origin. Temper is more abundant relative to clay paste than in the exotic Aru sherds, and there are no particles of volcanic ash (glass shards) imbedded in the pastes. Major grain types in each are the following (in approximate decreasing order of abundance, but quantitative petrography has not yet been attempted in the absence of apparent need to generate detailed data): plagioclase feldspar, volcanic rock fragments (varied internal textures), clinopyroxene, opaques, hornblende. The sherds from the islands near Halmahera afford no attractive grounds for a match with the exotic Aru sherds.

The sherd (74-4) from Pulau Kumo near Tobele on north Halmahera is much more promising, not an identical match but with close genetic affinities. One intriguing similarity is the presence of the same kind of glass shards (volcanic ash) imbedded in the clay paste. As this constituent has not been observed in 2000 Pacific island sherds, except for the exotic Aru sherds and the Pulau Kumo sherd, its presence is compatible with an origin for the exotic Aru sherds somewhere near Tobele on Halmahera. Additional data may show that many Indonesian ceramic suites (none examined personally to date) have analogous 'ash-in-paste' character, in which case the occurrence of glass shards in the pastes of the exotic Aru and the indigenous Pulau Kumo sherds may not alone be definitive of a close relationship.

The temper in the Pulau Kumo sherd is a distinctly finer grained sand than the tempers in the exotic Aru sherds, but a frequency count of 600 temper grains in the Pulau Kumo sherd shows that its mineralogical composition is statistically indistinguishable from the mean composition of the tempers in the exotic Aru sherds (Table 220-1). The standard deviation of the mean for each of five 
salient mineralogical constituents in eight Aru sherds overlaps with the standard deviation of the inherent counting error for the same constituents in the Pulau Kumo sherd. This congruence in composition, despite the difference in the coarseness of the tempers, when coupled with the unusual 'ash-in-paste' character of the both the exotic Aru sherds and the Pulau Kumo sherd, suggests the strong possibility that the exotic Aru wares were derived from Halmahera. Especially notable is the similarity of the volcanic rock fragments, which in both cases are dominantly silicic volcanic glass, in part pumiceous (microvesicular) with ragged margins suggestive of volcanic tephra and with internal textures (arrangement of glass and vesicles) that are visually indistinguishable.

Despite the similarities, however, between the Pulau Kumo sherd and exotic Aru sherds, additional work (in 2004) has shown that clay pastes in sherds from the volcanic island of Banda in the Banda Sea also contain vitroclastic ash visually indistinguishable from the ash in exotic Aru sherds. Moreover, the textures of indigenous Banda tempers and exotic Aru tempers are closely comparable (unlike the much finer grained temper sand in the Pulau Kumo sherd), and the mineralogical composition of the Banda temper is an even closer match for the temper in exotic Aru sherds than the Pulau Kumo temper. For these reasons, origin of the exotic Aru sherds on Banda, rather than Halmahera, seems the more robust inference.

Table 220-1: comparative compositions (grain frequency percentages) of temper sands in Pulau Kumo sherd from Halmahera and exotic Aru sherds ( $\mathrm{N}=8$; data from Petro Rpt WRD-212) where VRF=volcanic rock fragments

\begin{tabular}{lrr}
\hline GRAIN TYPE & $\begin{array}{r}\text { PULAU KUMO SHERD }(74-4) \\
\left( \pm \text { COUNTING ERROR, }\left(E^{1}\right)\right.\end{array}$ & $\begin{array}{r}\text { EXOTIC ARU SHERDS } \\
\left( \pm \text { STANDARD DEVIATION SD }{ }^{2}\right)\end{array}$ \\
\hline plagioclase feldspar & $40 \pm 2$ & $36 \pm 4$ \\
clinopyroxene & $6 \pm 1$ & $6 \pm 2$ \\
opaque iron oxides & $8 \pm 1$ & $10 \pm 6$ \\
microlitic VRF & $4 \pm 1$ & $3 \pm 2$ \\
vitric (glassy) VRF & $43 \pm 2$ & $45 \pm 2$ \\
\hline
\end{tabular}

$1 \mathrm{CE}=[\mathrm{p}(100-\mathrm{p}) / \mathrm{n}]^{1 / 2}$ where $\mathrm{p}$ is observed percentage and $\mathrm{n}$ is total grain count $(\mathrm{n}=600)$

2 SD is standard deviation of the mean for eight frequency counts (Petro Rpt WRD-212)

\section{Petrography of Sand Tempers in Sherds From Banda Naira and Ay in the Banda Islands of Eastern Indonesia}

Petrographic Report WRD-237 (15 June 2004)

Ten sherds from the Banda Islands sent by Peter Lape were examined petrographically in thin section with two aims in mind: (1) to establish the nature of Banda temper sands; and (2) to test whether exotic sherds in the Aru Islands to the east were possibly derived from Banda rather than Halmahera (as had previously been thought, but only provisionally without a robust temper match). Table 237-1 indicates the provenience of the Banda sherds examined in thin section.

\section{Temper Overview}

A contemporary sherd (\#OUW) from Ouw (Ouh) village on Saparua in the Lease Islands well north of Banda contains as temper a calcareous sand composed of globular foraminiferal tests that are hollow, and the vacuoles within the temper grains have in many cases been enlarged by leaching that has removed the thin calcareous walls of the tests (whether partial dissolution occurred during firing or later is impossible for me to determine). The temper is indistinguishable from the tempering materials from Ouw provided previously by Matthew Spriggs (Petro Rpt WRD-223): raw and cleaned modern tempering sand, a modern sherd, and a prehistoric sherd. As no additional provenance information can be gleaned from the Ouw sherd, its temper is not discussed further here. 
Table 237-1: Provenance of Banda sherds examined in thin section

\begin{tabular}{|c|c|c|}
\hline ISLAND & THIN SECTION LABEL & SHERD LABEL (AND DEPTH), LOCALE ON ISLAND \\
\hline \multirow{5}{*}{ Ay } & PAS & surface sherd near clay sources \\
\hline & $P A-1$ & PA-1-1 $(100-110 \mathrm{~cm})$, coast near south end \\
\hline & $P A-2 A$ & PA-2-2 $(100-125 \mathrm{~cm})$, north coast \\
\hline & $P A-2 B$ & PA-2-2 $(125-150 \mathrm{~cm})$, north coast \\
\hline & PA-9 & PA-9-1 (0-50 cm), near northeast tip \\
\hline \multirow[t]{4}{*}{ Banda Naira } & $\mathrm{BN}-1$ & BN-1-4 $(170-180 \mathrm{~cm})$, north coast \\
\hline & $\mathrm{BN}-4 \mathrm{~A}$ & BN-4-1 $(190-200 \mathrm{~cm})$, south coast \\
\hline & $\mathrm{BN}-4 \mathrm{~B}$ & BN-4-2 $(220-230 \mathrm{~cm})$, south coast \\
\hline & $\mathrm{BN}-4 \mathrm{C}$ & BN-4-2 $(235-250 \mathrm{~cm})$, south coast \\
\hline Saparua & ouW & Ouw village, Saparua (Lease Islands) \\
\hline
\end{tabular}

Sherd \#PA-1 from the calcareous islet of Ay is riddled with voluminous vacuoles that probably represent sites originally occupied by calcareous grains removed by leaching after burial (a common phenomenon in Oceanian sherd suites). The vacuoles are clearly visible megascopically as multiple closely spaced pits on the sherd surface. Tiny angular grains of plagioclase feldspar mineral grains, volcanic lithic fragments, opaque iron oxide grains, and clinopyroxene mineral grains are also present (in that approximate order of relative abundance). The terrigenous detritus may be natural temper imbedded within the clay body, perhaps as pyroclastic debris, but the comparable size of the terrigenous grains to the vacuoles left by removal of calcareous grains suggests instead that both calcareous and terrigenous detritus are components of a fine coastal sand added manually as temper to a clay body lacking aplastic impurities. The fine grain size and angular nature of the terrigenous debris leaves open the possibility that it was reworked from pyroclastic deposits on Ay, and mixed with calcareous detritus on local beaches. In either case, the paucity of terrigenous grains and the fine grain size of the temper make detailed analysis unrewarding, and the temper is not discussed further here (generically, however, it is similar to other pyroxene-bearing but hornblende-free temper sands in sherds from Ay and Banda Naira).

Most ( $n=6)$ of the other sherds from both Banda Naira $(n=3)$ and Ay $(n=3)$ contain as temper related pyroxene-bearing (but hornblende-free) feldspathic sands in which the dominant volcanic lithic fragments are composed of pumiceous felsic glass. This temper type is interpreted as indigenous to Banda, and variants are indistinguishable, texturally and compositionally, from the tempers in exotic sherds from Aru and Gorom.

Two sherds, one each from Ay and Banda Naira, contain hornblende-bearing volcanic temper sands that are both mineralogically and texturally unlike the pyroxene-bearing indigenous tempers, and may document ceramic transfer of exotic wares to Banda from some other volcanic island (Manuk to the south along the Banda chain being the closest geographically).

\section{Indigenous Temper Type}

The most abundant temper type in the Banda sherds is pyroxene-bearing feldspathic sand (Table 237-2) imbedded in clay pastes that contain a significant component of volcanic ash in the form of curvilinear and branching vitroclastic shards of felsic volcanic glass. Most abundant among the sand grains of the tempers are pumiceous glassy volcanic lithic fragments probably derived from volcanic source rocks closely related petrologically to the pyroclastic debris within the clay pastes. The tempers are appropriate in mineralogical composition for derivation from the volcanic assemblage of Banda, and the volcanic ash in the clay pastes was presumably derived from pyroclastic blankets that mantle islands of Banda. Much of the volcanic sand used for temper may 
well have been reworked from coarse ash deposits, but the moderately sorted and abraded (subangular to subrounded) character of the temper sands suggests that they were collected from stream deposits.

The indigenous Banda tempers in two sherds excavated from Ay (Table 237-2) are more feldspathic than the others, but contain the same grain types in different proportions and probably also derive from a volcanic island of Banda. Although they are not included in the calculation of the mean Banda temper composition (Table 237-3), they appear to represent but an end member of a gradational temper spectrum without sharp breaks. There seems little likelihood that volcanic aggregates of medium to coarse sand size occur on the calcareous islet of Ay, and all three Ay sherds containing the Banda temper type are inferred to reflect transport of finished wares (or temper sands) from a Banda volcanic island to Ay.

The four, less feldspathic indigenous Banda tempers, are texturally and compositionally indistinguishable from tempers in exotic sherds from Giri Gajah and Ondor on Gorom and from Wangil Midden and Karkur in the Aru Islands (Table 237-3). The exotic Aru-Gorom sherds also contain vitroclastic volcanic ash imbedded in their clay pastes. With both paste and temper so similar, prehistoric ceramic transfer from Banda to Gorom and Aru seems a robust conclusion to reach. Although one sherd from a Halmahera ceramic assemblage studied for comparative purposes contains volcanic ash in its paste and a temper sand compositionally similar to the exotic tempers in Aru-Gorom sherds (Petro Rpt WRD-220), the texture of the temper sand in the Halmahera sherd is quite different. By contrast, the temper match between indigenous Banda and exotic Aru-Gorom sherds seems exact and conclusive. No temper match between indigenous and exotic sherds anywhere in Pacific Oceania is any more robust.

\section{Exotic Temper Type}

The hornblende-bearing temper sands (Table 237-4) are placer aggregates that could not have been derived from concentration of ferromagnesian minerals from detritus like the feldspathic indigenous sands because the latter lack any hornblende mineral grains at all. One of the exotic temper sands $(\mathrm{BN}-4 \mathrm{C})$ is a well sorted subrounded aggregate, whereas the other (PA-9) is only

Table 237-2: frequency percentages of grain types in the indigenous pyroxene-bearing tempers of Banda sherds based on counts of $n$ sand grains in thin section (especially feldspathic tempers of PA-2A/PA-2B not included in mean composition of Table 237-3)

\begin{tabular}{lrrrrrr}
\hline GRAIN TYPE & $\begin{array}{r}\mathrm{BN}-1 \\
(n=235)\end{array}$ & $\begin{array}{r}\mathrm{BN}-4 \mathrm{~A} \\
(n=180)\end{array}$ & $\begin{array}{r}\mathrm{BN}-4 \mathrm{~B} \\
(n=185)\end{array}$ & $\begin{array}{r}\text { PAS } \\
(n=200)\end{array}$ & $\begin{array}{r}\text { PA-2A } \\
(n=105)\end{array}$ & $\begin{array}{r}\text { PA-2B } \\
(n=445)\end{array}$ \\
\hline quartz & $\mathrm{tr}$ & $\mathrm{tr}$ & $\mathrm{tr}$ & 1 & 0 & 0 \\
plagioclase & 33 & 29 & 43 & 33 & 57 & 48 \\
clinopyroxene & 2 & 4 & 5 & 6 & 10 & 6 \\
opaque Fe oxide & 5 & 9 & 7 & 8 & 1 & 2 \\
vitric (glassy) VRF & 59 & 56 & 42 & 51 & 29 & 40 \\
microlitic VRF & 1 & 2 & 3 & 1 & 3 & 4 \\
\hline
\end{tabular}

Table 237-3: comparative compositions of selected indigenous Banda tempers (Table 237-2) and of exotic tempers in sherds from Aru (Petro Rpts WRD-212, 221) and Gorom (Petro Rpt WRD-232) based on average percentages for $N$ thin sections ( \pm is SD)

\begin{tabular}{|c|c|c|c|}
\hline GRAIN TYPE & BANDA $(N=4)$ & GOROM $(N=7)$ & $\operatorname{ARU}(N=10)$ \\
\hline Quartz mineral grains & $\mathrm{tr}$ & $\mathrm{tr}$ & $\mathrm{tr}$ \\
\hline Plagioclase mineral grains & $35 \pm 5$ & $34 \pm 6$ & $37 \pm 4$ \\
\hline Clinopyroxene mineral grains & $4 \pm 1$ & $4 \pm 1$ & $6 \pm 2$ \\
\hline Opaque iron oxide grains & $7 \pm 2$ & $10 \pm 4$ & $10 \pm 5$ \\
\hline Vitric volcanic lithic fragments & $52 \pm 6$ & $50 \pm 3$ & $44 \pm 3$ \\
\hline Microlitic volcanic lithic fragments & $2 \pm 1$ & $2 \pm 1$ & $3 \pm 2$ \\
\hline
\end{tabular}


Table 237-4: frequency percentages of grain types in the exotic hornblende-bearing tempers of Banda sherds based on counts of 400 sand grains in each thin section

\begin{tabular}{lrrr}
\hline GRAIN TYPE & BN-4C & PA-9 & AVERAGE \\
\hline plagioclase feldspar & 47 & 42 & 45 \\
clinopyroxene & 7 & 11 & 9 \\
hornblende & 29 & 37 & 33 \\
opaque Fe oxides & 16 & 2 & 9 \\
volcanic lithics & 1 & 8 & 4 \\
\hline
\end{tabular}

moderately sorted and subangular, but both are probably beach sands, as judged both from their placer character and from the presence in both sherds of vacuoles that appear to represent sites where calcareous grains of hybrid beach sand have been leached from the sherds by postdepositional dissolution (but no calcareous grains remain). No discernible volcanic ash is present in the clay paste of either sherd, and this is an additional mark of distinction from the sherds interpreted as indigenous to Banda.

The origin of the sherds containing exotic hornblende-bearing tempers is indeterminate with present information, but their mineralogy is so different from the tempers thought to be indigenous to Banda that derivation from some other island is inferred. A source along the Banda chain of volcanic islands is the most attractive postulate geographically, but the Banda arc erupts mostly pyroxene andesite and the abundant hornblende in the exotic temper is accordingly anomalous. Conceivably, the sherds may reflect ceramic transfer to Banda from much farther afield. Search should be made for the nearest volcano erupting hornblende andesite, but my knowledge of the comparative volcanology of Indonesia is inadequate to that task and published literature available to me is not enlightening on that point.

\section{Summary of Temper Relations}

A majority of the Banda sherds contain plagioclase-rich and pyroxene-bearing temper sands (hornblende-free) that are inferred to be indigenous to Banda, and are imbedded in clay pastes that contain a significant component of vitroclastic volcanic ash presumably derived from ash blankets that mantle Banda. In thin section, the indigenous sherds are visually indistinguishable from exotic sherds recovered previously on Gorom and Aru, and comparison of the texture and mineralogical composition of the indigenous Banda temper type with tempers in the exotic Gorom-Aru sherds shows the three temper suites to be statistically indistinguishable. Ceramic transfer from Banda to both Gorom and Aru accordingly seems a robust inference. Subordinate Banda sherds containing hornblende-rich placer tempers are unlikely to derive from Banda, but apparently reflect ceramic transfer to Banda from elsewhere, either another volcanic island along the Banda chain or farther afield within Indonesia. 